\title{
Effects of nitrogen depletion on the biosorption capacities of Neochloris minuta and Neochloris alveolaris for five heavy metals
}

\author{
Dimitrios G. Giarikos ${ }^{1}$ [ - Jessica Brown ${ }^{1} \cdot$ Reza Razeghifard $^{1} \cdot$ Duy Vo $^{1} \cdot$ Ammy Castillo $^{1} \cdot$ Nikhil Nagabandi $^{1}$. \\ Justin Gaffney ${ }^{1} \cdot$ Miriam Zelden $^{1} \cdot$ Anna Antakshinova ${ }^{1} \cdot$ Sara Rodriguez ${ }^{1} \cdot$ Safiyah Muhammad ${ }^{1}$
}

Received: 23 March 2020 / Accepted: 7 January 2021 / Published online: 1 February 2021

(c) The Author(s) 2021

\begin{abstract}
Neochloris minuta and Neochloris alveolaris grown in nitrogen-rich $(+\mathrm{N})$ and nitrogen-depleted $(-\mathrm{N})$ media were tested for their heavy metal maximum biosorption capacities $\left(\mathrm{q}_{\max }\right)$ and adsorption percent efficiencies $(\mathrm{R} \%)$. By removing nitrogen from the growth media, both algal species showed an increase in their lipid content and a decrease in their protein content. Langmuir and Freundlich adsorption isotherms were used to determine the $\mathrm{q}_{\max }$ and adsorption efficiencies of the $+\mathrm{N}$ and $-\mathrm{N}$ algae in the recovery of $\mathrm{Pb}^{2+}, \mathrm{Cd}^{2+}, \mathrm{Zn}^{2+}, \mathrm{Cu}^{2+}$, and $\mathrm{Ni}^{2+}$. When comparing the two types of algae, N. alveolaris showed the highest adsorption capacities for all five metals either in $+\mathrm{N}$ or $-\mathrm{N}$ media. The maximum adsorption efficiency percentage of the lowest concentration metal ions for $N$. alveolaris was $87.10 \%$ for $\mathrm{Pb}^{2+}, 64.98 \%$ for $\mathrm{Cd}^{2+}, 59.50 \%$ for $\mathrm{Zn}^{2+}, 60.08 \%$ for $\mathrm{Cu}^{2+}$, and $50.61 \%$ for $\mathrm{Ni}^{2+}$. In both algae, nitrogen depletion (-N) caused an increase in the $\mathrm{q}_{\max }$ values for $\mathrm{Zn}^{2+}$ and $\mathrm{Cu}^{2+}$. Additionally, the $\mathrm{q}_{\max }$ of $N$. minuta for $\mathrm{Cd}^{2+}, \mathrm{Zn}^{2+}, \mathrm{Cu}^{2+}$ and $\mathrm{Ni}^{2+}$ increased by the nitrogen depletion demonstrating that the treatment can be applied to improve the biosorption capacity of a particular alga for multiple heavy metals. The biosorption capacity for these algae for heavy metals was also discussed in terms of their biomass compositions and the type of hard or soft metal acid based on the Pearson theory of Hard and Soft, Acid and Bases (HSAB).
\end{abstract}

Keywords Microalgae $\cdot$ Biosorption $\cdot$ Heavy metals $\cdot$ Biomass $\cdot$ Nitrogen depletion

\begin{tabular}{ll}
\multicolumn{2}{l}{ Abbreviation } \\
$N$. minuta & Neochloris minuta \\
$N$. alveolaris & Neochloris alveolaris \\
$\mathrm{q}_{\max }$ & Maximum adsorption capacity
\end{tabular}

\section{Introduction}

Heavy metals are considered persistent contaminants and emerging environmental pollutants because they cannot be destroyed or degraded (Ahmed et al. 2017; Park et al. 2010; Barrios-Estrada et al. 2018). The contamination of waters by heavy metals has been proven to affect the bioaccumulation of these pollutants in the food chain and human body (Jinsong He 2014). Conventional physiochemical methods

Dimitrios G. Giarikos

giarikos@nova.edu

1 Department of Chemistry and Physics, Halmos College of Natural Sciences and Oceanography, Nova Southeastern University, 3301 College Avenue, Ft. Lauderdale, FL 33314, USA of removing heavy metals from water include ion exchange (Dabrowski et al. 2004), chemical precipitation (Charerntanyarak 1999), electrokinetics (Yuan and Weng 2006), adsorption (Lee et al. 2012), and membrane processing (Abu Qdais and Moussa 2004). The applications of these techniques are limited due to the expensive chemicals required for treatment and the removal of heavy metals is often incomplete, which has shifted attention to "green agenda" strategies for the sustainable development of all modern societies.

A low cost and environmentally friendly alternative for sequestering heavy metal pollutants from water is through biosorption using dead biomass (Davis et al. 2003; Gupta et al. 2012). Algal biomasses have high sorption capacities and can be grown easily in open and closed bioreactors (Zeraatkar et al. 2016). Algal biomass has shown great promise as a biosorbent material to remove heavy metals from contaminated water due to their diverse multifunctional groups for binding metals, ease of growth for large scale cleanup, recyclability of captured metals, and excellent retention capacity (Nazal 2019; Samia Richards 2019; Rangbhashiyam 2019; Jinsong He 2014; Muhammad Bilal 
2018). Additionally, dry algal biomass can be stored for a long period and can be recycled.

Research in the field has primarily focused on brown algae (inter alia, Chromophyta) but has expanded to green algae (Chlorophyta), red algae (Rhodophyta) and even fungi and bacteria (Romera et al. 2007). For example, the bluegreen algae Spirulina maxima has been shown to remove up to $81.7 \%$ of the copper from wastewater (reducing the concentration from $42.7 \mathrm{ppb}$ to $7.8 \mathrm{ppb}$ ) after 10 days while the green algae Chlorella vulgaris removed up to $94.1 \%$ of the zinc (reducing the concentration from $9.54 \mathrm{ppb}$ to $0.6 \mathrm{ppb}$ ) (Chan et al. 2014). In some cases, algae can effectively remove metals from water in a matter of minutes. In one study, a dry powder of microalga Chlamydomonas microsphaera was able to remove $\mathrm{Cu}^{2+}$ at maximum adsorption capacity of $57.3 \mathrm{mg} \mathrm{g}^{-1}$ in less than an hour (Jiang et al. 2019).

Algal biomass is known to interact with heavy metal ions via surface precipitation, ion exchange, and/or complexation/ coordination (Jinsong He 2014). The functional groups of carbohydrates, proteins and lipids, which include amino, carboxyl, thiols, hydroxyl, sulfhydryl, imidazole, phosphate and phenolic groups, are responsible for coordinating with heavy metals (Rangbhashiyam 2019). In green algae, these functional groups play a dominant role in their metal-binding capacity (Gupta and Rastogi 2008; Sheng et al. 2004). It was shown the $-\mathrm{OH}, \mathrm{COO}-,-\mathrm{CH}$ and phosphate groups were the primary functional groups used for the biosorption of $\mathrm{Cd}$ (II) by Nannochloropsis oculate (Kaparapu and Prasad 2018).

The interactions between metal and algae can be observed microscopically as was the case during the biosorption of chromium by Chlorella sp. and Neochloris sp. (Kasimani et al. 2017). Using SEM, algal cells were seen to disaggregate and the cell surface became shorter with roughness following chromium absorption. The biosorption proceeded by a reduction of hexavalent chromium via complexation with carboxyl or amide or hydroxyl moieties of algal biomass. Similarly, during the process of copper biosorption by the surface of Chlorella vulgaris, the cell became more compact after the biosorption of $\mathrm{Cd}^{2+}$ to its porous surface; however, its surface became smoother (Kumar et al. 2018). Carboxyl, carbonyl, hydroxyl, amine and amido groups were identified as functional groups responsible for forming bonds with the $\mathrm{Cd}^{2+}$ ions. As an added benefit, the biosorption of $\mathrm{Cd}^{2+}$ by Chlorella vulgaris remained unaffected after five cycles of regeneration showing the suitability of algal biomass for commercial applications.

There are other factors, such as algae surface area, pore size, and nutrients, present in growth media that contribute to algae's ability to sequester metals. For Chlorella pyrenoidosa microalgae, the physical adsorption of cadmium ions was due to its $1.868 \mu \mathrm{m}$ macropores (Moreira et al. 2019). In another study, the removal of $\mathrm{Pb}^{2+}$ binding by Chlorella sp. was dependent on phosphorus concentration used in the growth medium for biomass production ( $\mathrm{Li}$ et al. 2019). The highest density of carboxyl and phosphoryl functional groups and therefore the largest maximum biosorption capacity of $\mathrm{Pb}^{2+}$ were obtained at $280 \mathrm{mg} \mathrm{L}^{-1}$ of $\mathrm{P}$. The increase in polyphosphate content of algal biomass was accompanied with substantial decreases in carbohydrate and protein content.

In this paper, we have studied the relationship between the biosorption of different heavy metals $\left(\mathrm{Pb}^{2+} \mathrm{Cd}^{2+}, \mathrm{Cu}^{2+}\right.$, $\mathrm{Zn}^{2+}$, and $\mathrm{Ni}^{2+}$ ) with the algal biomass composition. We chose two closely related species of green algae, Neochloris minuta and Neochloris alveolaris, and the most common non-biodegradable heavy metal contaminants found in water resources with different divalent ionic sizes $\left(\mathrm{Pb}^{2+}>\mathrm{Cd}^{2+}>\mathrm{Zn}^{2+}>\mathrm{Cu}^{2+}>\mathrm{Ni}^{2+}\right)$ and polarizabilities. Algal cells were grown in nitrogen-rich $(+\mathrm{N})$ or nitrogendepleted (-N) media to change their biomass compositions. We had previously shown that removing nitrogen from the growth medium caused an increase in the lipid content of $N$. minuta from 11 to $26 \%$ and decreases in the protein and the starch contents from $28.5 \%$ to $11.2 \%$ and from 45 to $41 \%$, respectively (Hastings 2018). For $N$. alveolaris $-\mathrm{N}$, the lipid content increased from 17 to $55 \%$ while its protein and starch content decreased from $30.8 \%$ to $9.0 \%$ and $27 \%$ to $14 \%$, respectively. This allowed us to evaluate how the biomass composition of an alga can affect its heavy metal biosorption capacities, adsorption efficiencies and capabilities by using Langmuir and Freundlich isotherm studies. These isotherm studies were used to predict the efficiency of the alga to remove these heavy metals from water (Romera et al. 2007; Gupta et al. 2011; Ncibi et al. 2008).

\section{Materials and methods}

\section{Chemicals}

Certified reference (TraceCert) metal standards of $1000 \mathrm{ppm}$ for lead, copper, nickel, zinc, and cadmium were purchased from Sigma Aldrich. Metal ion solutions were prepared by serial dilutions using $18 \mathrm{M} \Omega$ deionized water from a Barnstead water purification system. The solutions were adjusted to a $\mathrm{pH}=5$, using aqueous sodium hydroxide purchased from Sigma Aldrich.

\section{Algal growth and preparation}

N. minuta (UTEX 776) and N. alveolaris (UTEX B 836) cells were obtained from the culture collection of the University of Texas, Austin. The cells were cultured in a modified Bristol medium with the amounts of nutrients increased by six times and supplemented with trace metal ions of BG-11 
medium (Supplementary Tables S1 and S2)(Anderson 2005). The primary purpose of increasing the amount of nutrients was to avoid reaching nutrient-limiting conditions during growth. Pyrex round media bottle (2-L wide-mouth bottles, Sigma Aldrich CLS13972L) was altered to culture bottles by fitting their screw caps with inlet and exit port connections for air (Supplementary Figure S1). An Active AQUA AAPA110L pump delivering an airflow of $80 \mathrm{~mL} / \mathrm{min}$ bubbled through a 12-mm coarse air stone (Fisher Scientific 11-138B) supplied air. The air was passed through a $50 \mathrm{~mm}$ inline PTFE membrane with $0.45 \mu \mathrm{m}$ pore size (Fisher Scientific $09-740-37 \mathrm{~L}$ ) to prevent introducing contamination. The temperature of the culture was maintained at $30 \pm 2{ }^{\circ} \mathrm{C}$. The cultures were illuminated from both sides with two T5 high output fluorescent lighting systems (EnviroGro) each having four light tubes. The incident light intensity on the surface of the bottle was $180 \pm 20 \mu \mathrm{E} \mathrm{m}^{-2} \mathrm{~s}^{-1}$ measured by a MQ-200 Quantum Sensor (Apogee Instruments Inc. Logan, UT, USA). The light sources were switched on and off by a time-controlled outlet strip to give cultures $14 \mathrm{~h}$ of light. The $N$. minuta and $N$. alveolaris cells were first collected from agar plates and grown for 5 days in $+\mathrm{N}$ medium (with the addition of $\mathrm{NaNO}_{3}$ ) at $30 \pm 2{ }^{\circ} \mathrm{C}$ (Supplementary Figure S1). The algal cells were collected by removing the growth medium by centrifugation at $5000 \mathrm{rpm}$, for $5 \mathrm{~min}$, at $15^{\circ} \mathrm{C}$ using a Beckman Coulter Optima Max-XP refrigerated centrifuge. The cell pellets were washed with milli-Q water before they were regrown for an additional 5 days in $+\mathrm{N}$ or $-\mathrm{N}$ media. Overnight sedimentation and centrifugation were then applied to harvest the cells. The harvested algal cells were dried under high vacuum $\left(1 \times 10^{-4}\right.$ torr $)$ in a $50^{0} \mathrm{C}$ water bath using a Schlenk line and a Welch DuoSeal 1402 high vacuum pump for 3-5 h in a $100 \mathrm{~mL}$ Pyrex round bottle. The dry biomass yield was determined using an analytical scale. The dried algal cells were stored in $20 \mathrm{~mL}$ scintillation vials at $-20{ }^{\circ} \mathrm{C}$ and when ready to use, sieved to obtain uniform particles of $0.75-1.00 \mathrm{~mm}$ average diameter.

\section{Total triacylglyceride measurements}

Total triacylglyceride (TAG) concentrations were measured using the infinity triglycerides reagent (TR-22421 Fisher Scientific). Initially, $10 \mathrm{mg}$ of dried algae was suspended in $1 \mathrm{~mL}$ of $4 \mathrm{M} \mathrm{NaOH}$ and heated at $80^{\circ} \mathrm{C}$ for $1 \mathrm{~h}$. The solution was then neutralized with $2 \mathrm{M} \mathrm{HCl} .180 \mu \mathrm{L}$ of sample was mixed with $1.5 \mathrm{~mL}$ of triglycerides reagent in a $2 \mathrm{~mL}$ microcentrifuge tube and incubated on a shaker at $37^{\circ} \mathrm{C}$ for $10 \mathrm{~min}$ and $200 \mathrm{rpm}$. Absorbance readings were taken at $600 \mathrm{~nm}$ and the total concentration of TAGs was calculated from a calibration graph constructed from different concentrations of glycerltripalmitate (T5888 Sigma-Aldrich). The $10 \mathrm{mg} / \mathrm{mL}$ glycerltripalmitate standard was treated with the same saponification procedure explained above prior to reacting it with the Infinity Triglycerides Reagent.

\section{Starch measurements (Hastings 2018)}

Starch was measured by digesting $0.3 \mathrm{~mL}$ of algal sample prepared for TAG measurements with $50 \mu \mathrm{L}$ of amyloglucosidase enzyme (A7095 Sigma-Aldrich) in $1 \mathrm{~mL}$ (total volume) of $50 \mathrm{mM}$ acetate buffer $(\mathrm{pH}=4.8)$ on a shaker at $60{ }^{\circ} \mathrm{C}$ for $30 \mathrm{~min}$ and $200 \mathrm{rpm}$. The amyloglucosidase enzyme was dialyzed three times against $50 \mathrm{mM}$ acetate buffer $(\mathrm{pH}=4.8)$ at $4{ }^{\circ} \mathrm{C}$ overnight. $0.1 \mathrm{~mL}$ of the digested sample was mixed with $0.9 \mathrm{~mL}$ of glucose reagent and incubated at $37{ }^{\circ} \mathrm{C}$ for $5 \mathrm{~min}$. The starch concentration was calculated by converting the absorbance reading at $340 \mathrm{~nm}$ to glucose concentration using $E \mathrm{NADH}=6.22 \mathrm{mM}^{-1} \mathrm{~cm}^{-1}$. As a control, a calibration graph was constructed from a $10 \mathrm{mg} / \mathrm{mL}$ solution of starch made in $1 \mathrm{~mL}$ of $4 \mathrm{M} \mathrm{NaOH}$ and heated at $80^{\circ} \mathrm{C}$ for $5 \mathrm{~min}$. The starch solution needs to be neutralized with $2 \mathrm{M} \mathrm{HCl}$ prior to the digestion with the amyloglucosidase enzyme.

\section{Protein measurement (Hastings 2018)}

The percentage nitrogen for the algal samples was determined by triplicate elemental analyses of the dried algae by Micro-Analysis Inc., Wilmington, DE. The $\%$ protein in the algae was calculated using 4.78 as the nitrogen-to-protein conversion factor defined for microalgae (Lourenco et al. 2004).

\section{Biosorption experiments}

Algal cells $(20 \pm 0.1 \mathrm{mg})$ were added to scintillation vials with $20 \mathrm{~mL}$ of the metal ion solution at a known concentration ranging from 10-250 ppm. Several trials were performed to determine the maximum adsorption using Langmuir isotherms. The ideal concentration ranges were 50-250 ppm for lead, 20-100 ppm for cadmium, 30-70 ppm for zinc, and 10-50 ppm for copper and nickel. The solutions were stirred with a stir bar at a speed of $1200 \mathrm{rpm}$ at room temperature $\left(22-23^{\circ} \mathrm{C}\right)$ for $1 \mathrm{~h}$. The solutions were then centrifuged at $5000 \mathrm{rpm}$ and $15^{\circ} \mathrm{C}$ to separate algal cells before they were filtered with a $0.22 \mu \mathrm{m}$ pore size $30 \mathrm{~mm}$ sterile syringe filter to remove any residual algal cells. The concentration of the remaining metal ion solution was determined using atomic absorption spectroscopy (Shimadzu AA-6200) with the instrumental parameters given in Supplementary Table S3. The performance of algal biomass for the removal of metal ions from the solution was quantitatively evaluated using the amount of metal ions adsorbed on the mass unit of algal biomass $\left(\mathrm{q}_{\mathrm{e}}, \mathrm{mg} / \mathrm{g}\right)$, Eq. 1 and percent of metal ions adsorbed (R \%, adsorption efficiency), Eq. 2 :

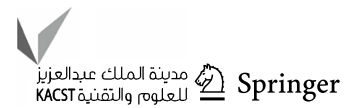


$q_{\mathrm{e}}=\left(C_{\mathrm{o}}-C_{\mathrm{e}}\right) \frac{V}{m}$

$R \%=\frac{C_{\mathrm{o}}-C_{\mathrm{e}}}{C_{\mathrm{o}}} * 100$

where $C_{\mathrm{o}}$ is the initial metal ion concentration $(\mathrm{mg} / \mathrm{L}), \mathrm{Ce}$ the final metal ion concentration $(\mathrm{mg} / \mathrm{L}), \mathrm{V}$ the volume of the metal ion solution $(\mathrm{L})$, and $\mathrm{m}$ the mass of algal cells $(\mathrm{g})$.

\section{Biosorption isotherms}

Langmuir and Freundlich adsorption isotherm models were used to describe how algae adsorb metal ions. The Langmuir model assumes monolayer adsorption of a uniform surface with a finite number of adsorption sites. Once a site is filled, no further sorption can take place. The surface will reach saturation point where the maximum adsorption of the surface will be achieved $\left(\mathrm{q}_{\max }\right)$. The linear form for the Langmuir model is described as Eq. 3:(Langmuir 1918)

$\frac{C_{\mathrm{e}}}{q_{\mathrm{e}}}=\frac{1}{K_{\mathrm{L}} q_{\max }}+\frac{1}{q_{\max }} C_{\mathrm{e}}$

where $q_{\text {max }}$ is the maximum monolayer adsorption capacity $(\mathrm{mg} / \mathrm{g})$ or the amount of metal that algae can bind; $\mathrm{K}_{\mathrm{L}}$ is the Langmuir isotherm constant $(\mathrm{L} / \mathrm{mg})$, representing affinity and the energy of adsorption; $\mathrm{q}_{\mathrm{e}}$ is the equilibrium adsorbent phase concentration of the metal $(\mathrm{mg} / \mathrm{L})$; and $\mathrm{C}_{\mathrm{e}}$ is the equilibrium aqueous-phase concentration of metal $(\mathrm{mg} / \mathrm{L})$. To predict the affinity between sorbate (heavy metals) and sorbent (algae), the separation factor or dimensionless equilibrium parameter $\mathrm{R}_{\mathrm{L}}$ is calculated using the following Eq. 4:

$R_{\mathrm{L}}=\frac{1}{1+K_{\mathrm{L}} C_{\mathrm{o}}}$

where $C_{\mathrm{o}}$ is the maximum initial concentration of metal ions $(\mathrm{mg} / \mathrm{L})$. The value of separation parameter $\mathrm{R}_{\mathrm{L}}$ indicates the type of isotherm to be favorable $\left(0<R_{\mathrm{L}}<1\right)$. Values of the Langmuir parameters $q_{\max }$ and $K_{\mathrm{L}}$ were calculated from the slope and intercept of the linear plot of $C_{\mathrm{e}} / q_{\mathrm{e}}$ versus $C_{\mathrm{e}}$.

The Freundlich model assumes adsorption on heterogeneous surfaces and the application of the Freundlich equation suggests that sorption energy exponentially decreases on completion of the sorption centers on an adsorbent. The linear form for the Freundlich model is described as Eq. 5:(Heller and Wilfried 1939)

$\log q_{e}=\log K_{F}+\frac{1}{n} \log C_{e}$

where $K_{\mathrm{F}}$ is the Freundlich isotherm constant that represents the sorption capacity of the metal ions or the binding energy. $1 / n$ is the heterogeneity factor and $n(g / L)$ is a measure of the deviation from linearity of adsorption. Freundlich equilibrium constants were determined from the plot of $\log q_{\mathrm{e}}$ versus $\log C_{\mathrm{e}}$. The n value indicates the degree of nonlinearity between solution concentration and adsorption. If $n=1$, adsorption is linear, if $n>1$ adsorption is a physical process, and if $n<1$ adsorption is a chemical process.

\section{Results and discussion}

\section{Biomass composition}

Table 1 provides the biomass composition (starch, lipid, and protein content) data for $N$. minuta and $N$. alveolaris grown in nitrogen-rich $(+\mathrm{N})$ and depleted $(-\mathrm{N})$ media. To create these two different growth conditions, algal cells were first grown in $+\mathrm{N}$ medium. Algal cells were then collected under nonsterile conditions transferred into $-\mathrm{N}$ medium and grown for five additional days. Overnight sedimentation, centrifugation and washing were then applied to harvest and store algal cells. The harvested algal cells were dried, weighed, and stored until biomass composition analysis and use.

The data shows that $\mathrm{N}$ deprivation caused a substantial decrease in protein content from $28.5 \% \pm 0.2$ to $11.2 \% \pm 0.1$ and $30.8 \% \pm 0.2$ to $9.0 \% \pm 0.1$ for $N$. minuta and $N$. alveolaris, respectively. These relatively large decreases in the protein content are accompanied with large increases in lipid content. Nitrogen depletion caused a larger increase in the lipid content in $N$. alveolaris (from $17.0 \% \pm 0.2$ to $55.0 \% \pm 2.4$ ) than $N$. minuta $(11.0 \% \pm 0.8$ to $26.0 \% \pm 1.1)$. A decrease in the starch content was observed for $N$. alveolaris (from $27.0 \% \pm 2.8$ to $14.0 \% \pm 3.1$ ) but not for $N$. minuta (from $45 \% \pm 5.6$ to $41 \% \pm 2.8)$ when cells were subjected to nitrogen deprivation. These modifications to biomass composition provided four algal samples: $N$. minuta and $N$. alveolaris in $+\mathrm{N}$ and $-\mathrm{N}$ media.

Table 1 Biomass composition after 10 days of growth of $N$. minuta and $N$. alveolaris algae cells in nitrogen-rich $(+\mathrm{N})$ and nitrogendepleted (-N) media

\begin{tabular}{llll}
\hline Algae & Lipid \% & Starch \% & Protein \% \\
\hline N. Minuta, $+\mathrm{N}$ & $11 \pm 0.8$ & $45 \pm 5.6$ & $28.5 \pm 0.2$ \\
N. Minuta, $-\mathrm{N}$ & $26 \pm 1.1$ & $41 \pm 2.8$ & $11.2 \pm 0.1$ \\
Ratio (-N/+N) & 2.36 & 0.91 & 0.39 \\
N. Alveolaris, $+\mathrm{N}$ & $17 \pm 0.2$ & $27 \pm 2.8$ & $30.8 \pm 0.2$ \\
N. Alveolaris, -N & $55 \pm 2.4$ & $14 \pm 3.1$ & $9.0 \pm 0.1$ \\
Ratio (-N/+N) & 3.24 & 0.52 & 0.29 \\
\hline
\end{tabular}




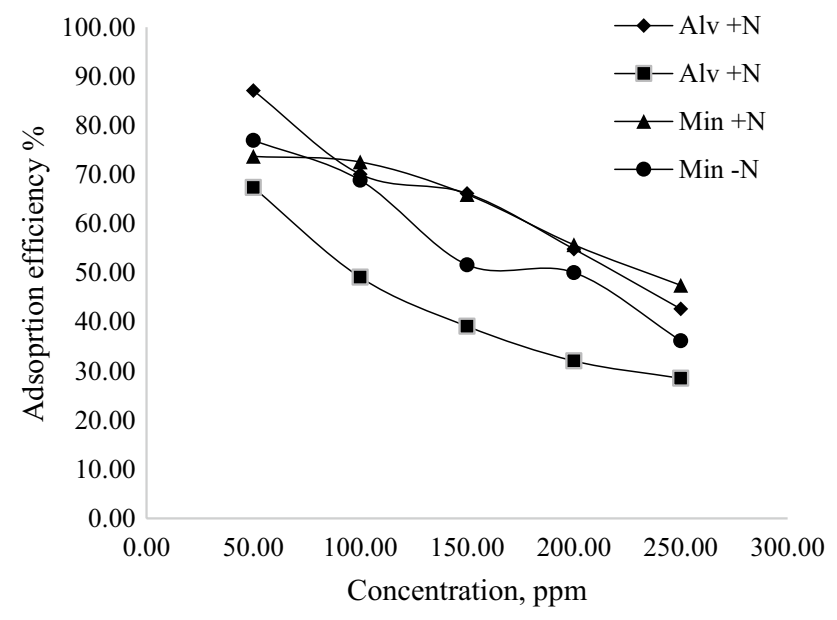

Fig. 1 Effect of initial ion concentration on the adsorption efficiency of $\mathrm{Pb}^{2+}$ onto $N$. alveolaris $+\mathrm{N}, N$. alveolaris $-\mathrm{N}, N$. minuta $+\mathrm{N}$, and $\mathrm{N} /$ minuta $-\mathrm{N}$ algae

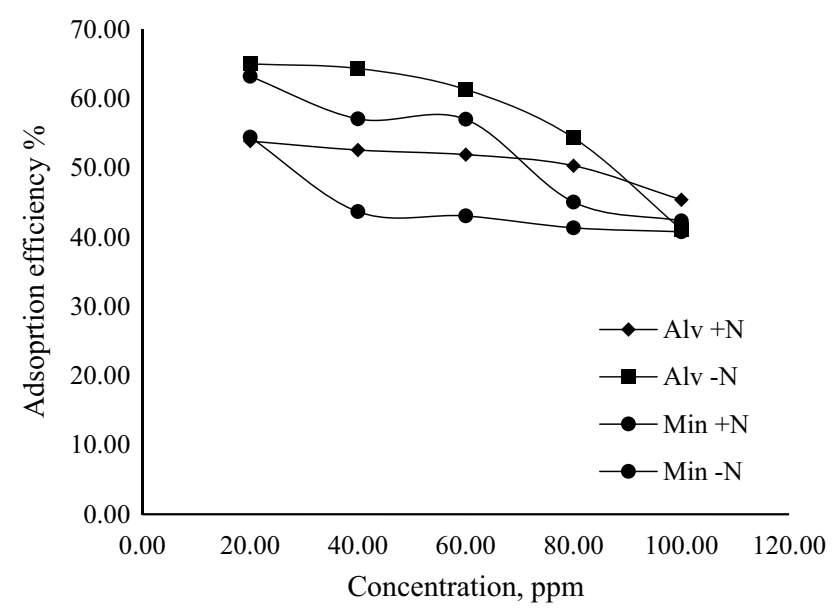

Fig. 2 Effect of initial ion concentration on the adsorption efficiency of $\mathrm{Cd}^{2+}$ onto $N$. alveolaris $+\mathrm{N}, N$. alveolaris $-\mathrm{N}, N$. minuta $+\mathrm{N}$, and $N /$ minuta $-\mathrm{N}$ algae

\section{Chemical composition and metal ion influence on absorption efficiency}

The metal ion concentration plays an important role on the adsorption efficiency and the amount of metal ions adsorbed from the medium. The algal cells exhibited the highest adsorption efficiencies at lower concentrations while the gradual increase in the metal ion concentrations led to a decrease in adsorption efficiencies, which is a result of saturation. Saturation occurs because the number of adsorbent sites is constant and the continuous increase in the metal ion concentration leads to the utilization of all of the active adsorption sites (Abbas 2017).

Figures 1, 2, 3, 4 and 5 show the effect of the initial ion concentrations on the adsorption efficiencies of the five

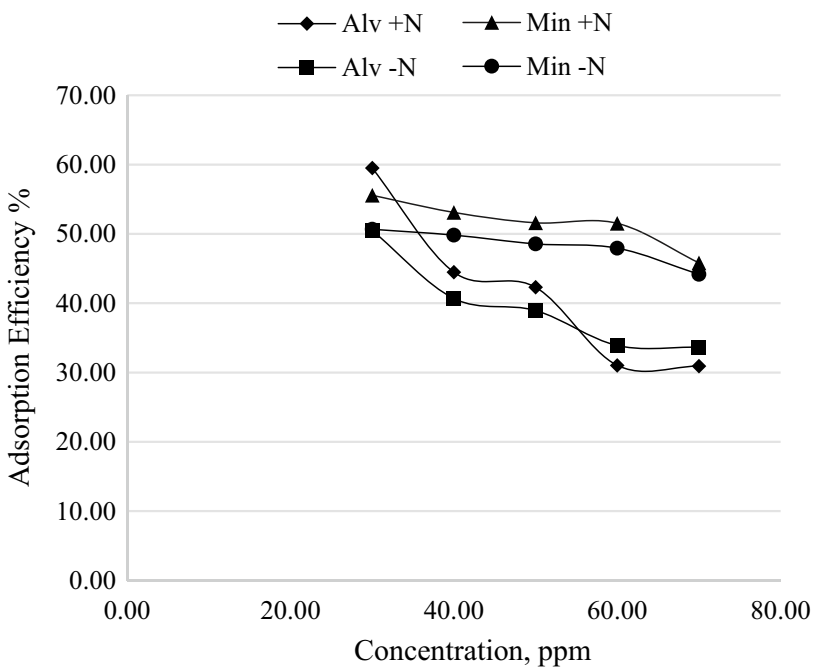

Fig. 3 Effect of initial ion concentration on the adsorption efficiency of $\mathrm{Zn}^{2+}$ onto $N$. alveolaris $+\mathrm{N}, N$. alveolaris $-\mathrm{N}, N$. minuta $+\mathrm{N}$, and $\mathrm{N} /$ minuta $-\mathrm{N}$ algae

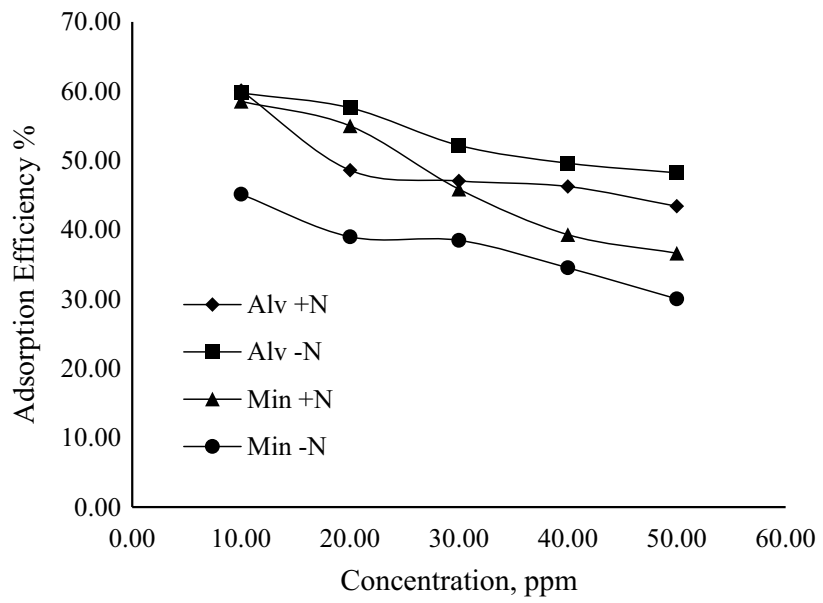

Fig. 4 Effect of initial ion concentration on the adsorption efficiency of $\mathrm{Cu}^{2+}$ onto $N$. alveolaris $+\mathrm{N}, N$. alveolaris $-\mathrm{N}, N$. minuta $+\mathrm{N}$, and $N /$ minuta $-\mathrm{N}$ algae

heavy metals onto $N$. minuta $(+\mathrm{N}$ and $-\mathrm{N})$ and $N$. alveolaris $(+\mathrm{N}$ and $-\mathrm{N})$. The maximum adsorption efficiency percentage of the lowest concentration metal ions for all four types of algae ranged $67.37-87.10 \%$ for $\mathrm{Pb}^{2+}, 53.84-64.98 \%$ for $\mathrm{Cd}^{2+}, 50.50-59.50 \%$ for $\mathrm{Zn}^{2+}, 45.13-60.08 \%$ for $\mathrm{Cu}^{2+}$, and $41.12-50.61 \%$ for $\mathrm{Ni}^{2+}$ (Table 2). The highest adsorption efficiency $(87.10 \%$ metal ion removed) was achieved for $\mathrm{Pb}^{2+}$ with the lowest concentration of metal ion (50 ppm) and the lowest adsorption efficiency $(41.12 \%$ metal ion removed) occurred with $\mathrm{Ni}^{2+}(10 \mathrm{ppm})$. When comparing the two species of algae, $N$. alveolaris provided higher adsorption capacities for all the metals, which is interpreted as having the most active sites. Of the two compositions of 


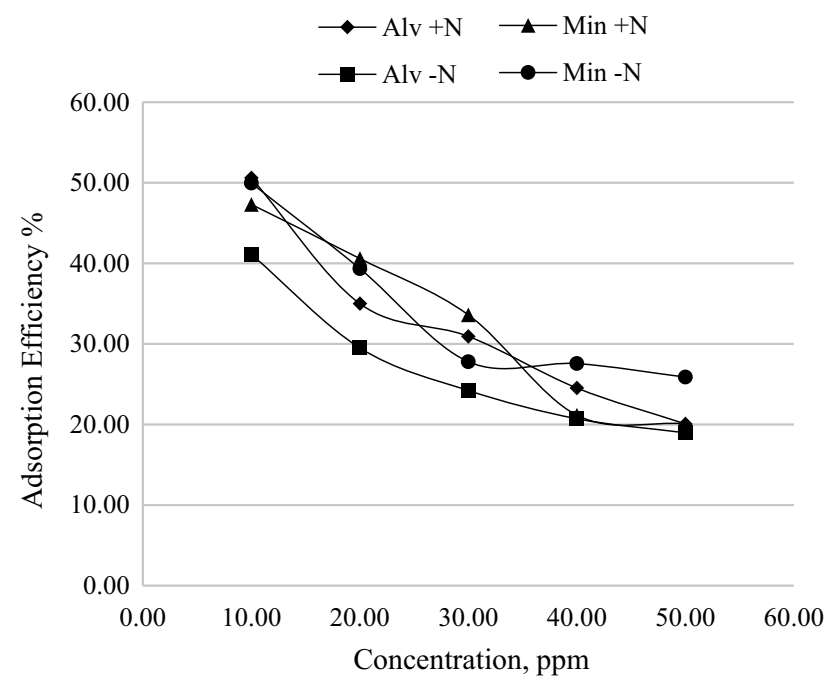

Fig. 5 Effect of initial ion concentration on the adsorption efficiency of $\mathrm{Ni}^{2+}$ onto $N$. alveolaris $+\mathrm{N}, N$. alveolaris $-\mathrm{N}, N$. minuta $+\mathrm{N}$, and $\mathrm{N} /$ minuta $-\mathrm{N}$ algae

Table 2 The maximum adsorption efficiency $\%$ of the lowest concentration metal ions tested with each algae and their biomass composition: Neochloris alveolaris $+\mathrm{N}($ Alv $+\mathrm{N})$, Neochloris alveolaris $-\mathrm{N}$ $($ Alv $-\mathrm{N})$, Neochloris minuta $+\mathrm{N}($ Min $+\mathrm{N})$, and Neochloris minuta $-\mathrm{N}$ $(\operatorname{Min}-\mathrm{N})$

\begin{tabular}{lllll}
\hline Metal and Algae & $\begin{array}{l}\text { Adsorption } \\
\text { Efficiency \% }\end{array}$ & Lipid \% & Starch \% & Protein \% \\
\hline
\end{tabular}

\section{$\mathbf{P b}$}

\begin{tabular}{|c|c|c|c|c|}
\hline $\mathrm{Alv}+\mathrm{N}$ & 87.10 & 17 & 27 & 30.8 \\
\hline Alv $-\mathrm{N}$ & 67.37 & 55 & 14 & 9.0 \\
\hline $\operatorname{Min}+\mathrm{N}$ & 73.70 & 11 & 45 & 28.5 \\
\hline $\operatorname{Min}-\mathrm{N}$ & 76.97 & 26 & 41 & 11.2 \\
\hline \multicolumn{5}{|l|}{ Cd } \\
\hline $\mathrm{Alv}+\mathrm{N}$ & 53.84 & 17 & 27 & 30.8 \\
\hline Alv -N & 64.98 & 55 & 14 & 9.0 \\
\hline $\operatorname{Min}+\mathrm{N}$ & 54.41 & 11 & 45 & 28.5 \\
\hline $\operatorname{Min}-\mathrm{N}$ & 63.18 & 26 & 41 & 11.2 \\
\hline \multicolumn{5}{|l|}{$\mathbf{Z n}$} \\
\hline $\mathrm{Alv}+\mathrm{N}$ & 59.50 & 17 & 27 & 30.8 \\
\hline Alv -N & 50.50 & 55 & 14 & 9.0 \\
\hline $\operatorname{Min}+\mathrm{N}$ & 55.57 & 11 & 45 & 28.5 \\
\hline $\operatorname{Min}-\mathrm{N}$ & 50.67 & 26 & 41 & 11.2 \\
\hline \multicolumn{5}{|l|}{$\mathrm{Cu}$} \\
\hline $\mathrm{Alv}+\mathrm{N}$ & 60.08 & 17 & 27 & 30.8 \\
\hline Alv -N & 59.73 & 55 & 14 & 9.0 \\
\hline $\mathrm{Min}+\mathrm{N}$ & 58.54 & 11 & 45 & 28.5 \\
\hline $\operatorname{Min}-\mathrm{N}$ & 45.13 & 26 & 41 & 11.2 \\
\hline \multicolumn{5}{|l|}{$\mathbf{N i}$} \\
\hline $\mathrm{Alv}+\mathrm{N}$ & 50.61 & 17 & 27 & 30.8 \\
\hline Alv $-\mathrm{N}$ & 41.12 & 55 & 14 & 9.0 \\
\hline $\mathrm{Min}+\mathrm{N}$ & 47.31 & 11 & 45 & 28.5 \\
\hline $\operatorname{Min}-\mathrm{N}$ & 49.95 & 26 & 41 & 11.2 \\
\hline
\end{tabular}

$N$. alveolaris, the $+\mathrm{N}$ had the highest adsorption efficiencies overall for all the metals, except for $\mathrm{Cd}^{2+}$, where $-\mathrm{N}$ provided the highest value.

When assessing whether changing the composition of algae could improve the adsorption efficiency of any the metals, the results showed that $-\mathrm{N}$ type algae were able to increase the adsorption efficiency of some of the metals. Specifically, N. minuta $-\mathrm{N}$ improved the adsorption efficiency of $\mathrm{Pb}^{2+}, \mathrm{Cd}^{2+}$, and $\mathrm{Ni}^{2+}$ and $N$. alveolaris $-\mathrm{N}$ improved for $\mathrm{Cd}^{2+}$.

By comparing the adsorption efficiencies with the composition of the algal types (+ $\mathrm{N}$ vs. $-\mathrm{N})$, we were able to provide some insight on how the two were related. For $\mathrm{Pb}^{2+}$ and $\mathrm{Ni}^{2+}$, the starch content inversely effected the adsorption efficiency. $N$. alveolaris $+\mathrm{N}$ had nearly twice the amount of starch than $N$. alveolaris $-\mathrm{N}$, resulting in a decline in absorption efficiency for the $-\mathrm{N}$ type. However, the starch content was practically unchanged for $N$. minuta algae grown in $-\mathrm{N}$ medium, which resulted in an unaffected adsorption efficiency. For $\mathrm{Cd}^{2+}$, the lipid content effected the adsorption efficiency. By growing the algae in a nitrogen-depleted (-N) environment, the lipid content increased, which improved the adsorption efficiency of $\mathrm{Cd}^{2+}$ for both $N$. alveolaris and $N$. minuta. For $\mathrm{Zn}^{2+}$ and $\mathrm{Cu}^{2+}$, the protein content affected the adsorption efficiency. In a nitrogen-depleted environment, the protein content of each algae drastically decreased, which also lowered the adsorption efficiency for both $N$. alveolaris $-\mathrm{N}$ and $N$. minuta $-\mathrm{N}$ types.

Algal composition is significant when considering which algae to use to remove heavy metals from contaminated waters. Their adsorption efficiencies will depend on the species of the algae and the nitrogen content in the water, since nitrogen deprivation changes their biomolecular composition. For both $N$. alveolaris and $N$. minuta species, nitrogen deprivation increased the adsorption efficiencies for $\mathrm{Cd}^{2+}$ and decreased for $\mathrm{Zn}^{2+}$ and $\mathrm{Cu}^{2+}$. In the cases for $\mathrm{Pb}^{2+}$ and $\mathrm{Ni}^{2+}$, the adsorption efficiencies decreased for $N$. alveolaris -N and increased for $N$. minuta $-\mathrm{N}$ compared to the nitrogenrich species.

\section{Linear fitting of the isotherm models and biomass affinity}

An adsorption isotherm was used to understand the mechanism of adsorption of the heavy metal ions onto the algae and to quantitatively assess the distribution of the metal ions at equilibrium between the liquid and solid phase. The isotherms determine the maximum capacity of metal adsorption on the algae in terms of the amount of metal ions taken up by the algae per unit mass $\left(\mathrm{mg} \mathrm{g}^{-1}\right)$ of the algae. The data were fitted to both Langmuir and Freundlich isotherms to find the most appropriate model for the metal ions adsorption on the algae. Figures 6, 7, 8, 9, 10, 11, 12, 13, 14 and 15 


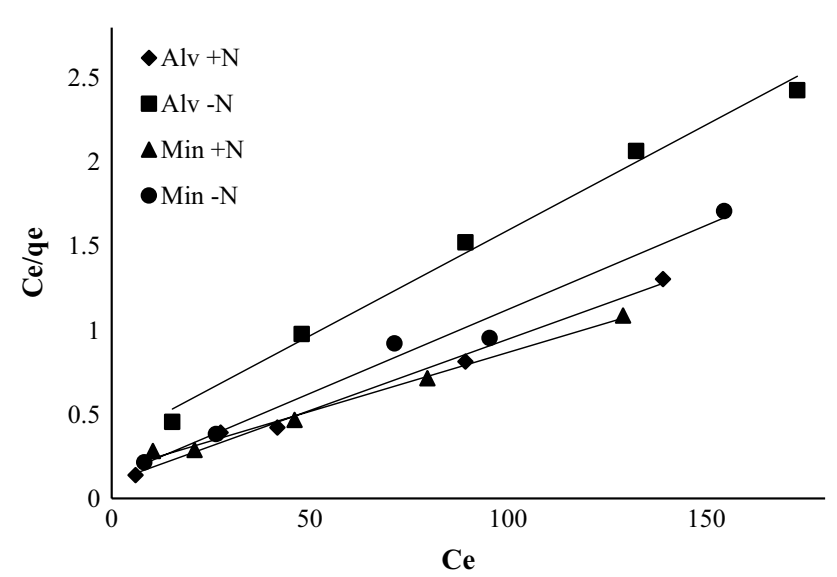

Fig. 6 Langmuir isotherm for lead ions onto $N$. alveolaris $+\mathrm{N}, N$. alveolaris $-\mathrm{N}, N$. minuta $+\mathrm{N}$, and $\mathrm{N} /$ minuta $-\mathrm{N}$ algae

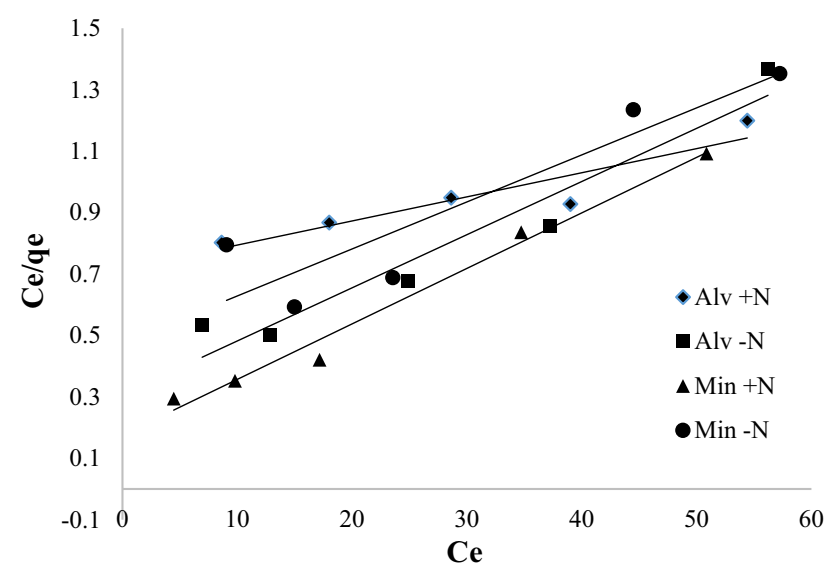

Fig. 7 Langmuir isotherm for cadmium ions onto $N$. alveolaris $+\mathrm{N}$, $N$. alveolaris $-\mathrm{N}, N$. minuta $+\mathrm{N}$, and $N /$ minuta $-\mathrm{N}$ algae

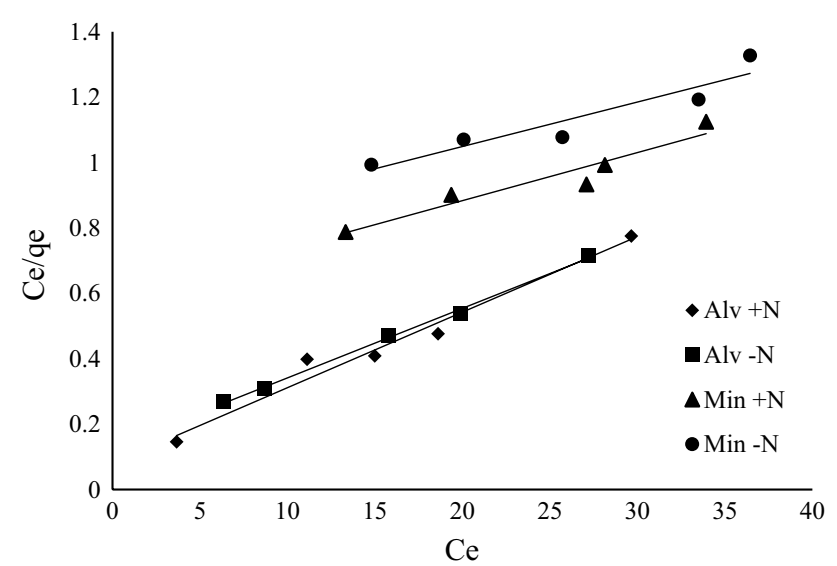

Fig. 8 Langmuir isotherm for zinc ions onto $N$. alveolaris $+\mathrm{N}, N$. alveolaris $-\mathrm{N}, N$. minuta $+\mathrm{N}$, and $N /$ minuta $-\mathrm{N}$ algae

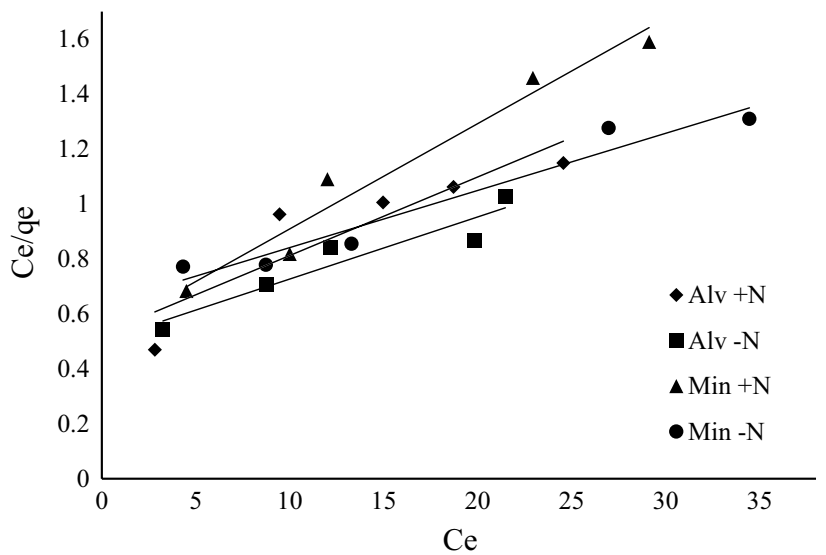

Fig. 9 Langmuir isotherm for copper ions onto $N$. alveolaris $+\mathrm{N}, N$. alveolaris $-\mathrm{N}, N$. minuta $+\mathrm{N}$, and $N /$ minuta $-\mathrm{N}$ algae

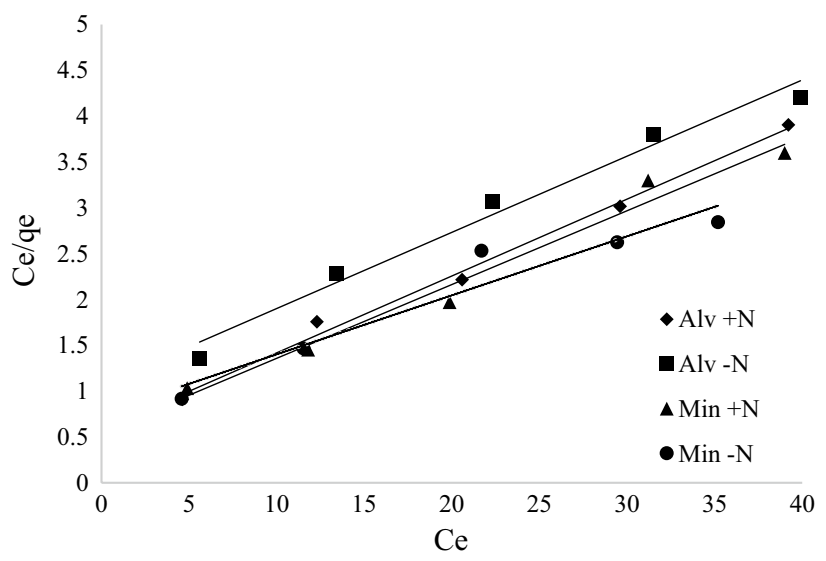

Fig. 10 Langmuir isotherm for nickel ions onto $N$. alveolaris $+\mathrm{N}, N$. alveolaris $-\mathrm{N}, N$. minuta $+\mathrm{N}$, and $N /$ minuta $-\mathrm{N}$ algae

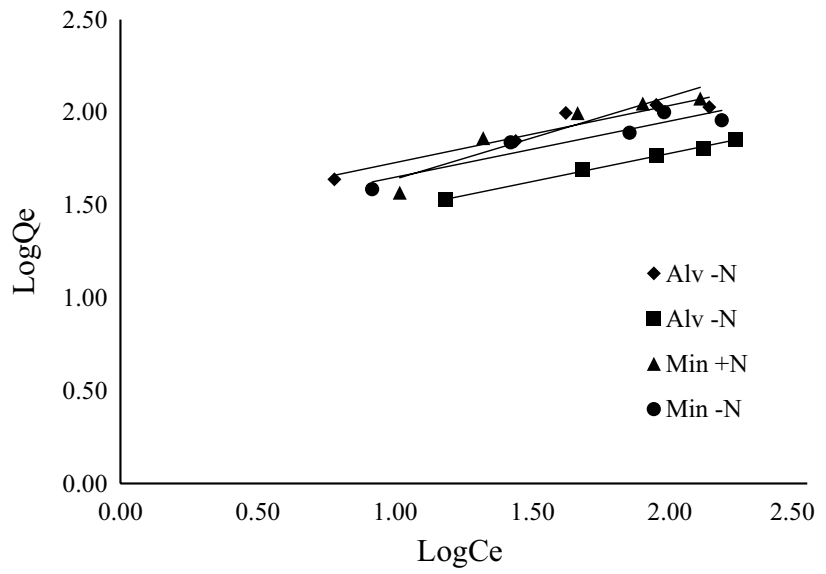

Fig. 11 Freundlich isotherm for lead ions onto $N$. alveolaris $+\mathrm{N}, N$. alveolaris $-\mathrm{N}, N$. minuta $+\mathrm{N}$, and $N /$ minuta $-\mathrm{N}$ algae 


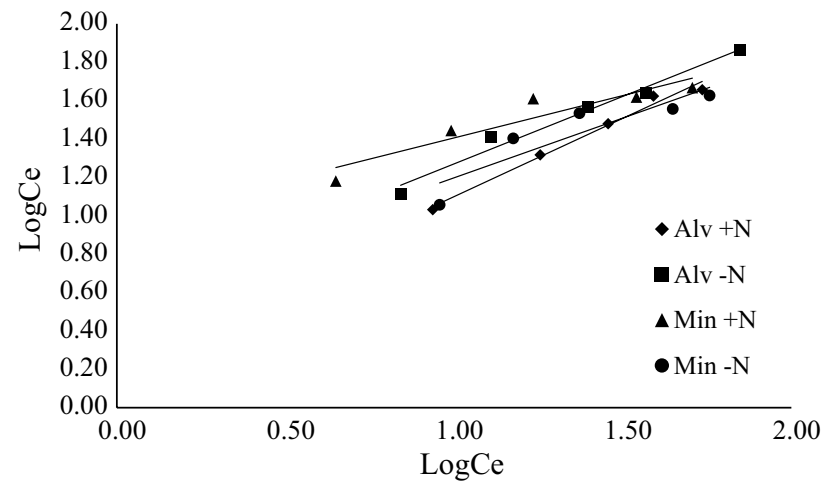

Fig. 12 Freundlich isotherm for cadmium ions onto $N$. alveolaris $+\mathrm{N}$, $N$. alveolaris $-\mathrm{N}, N$. minuta $+\mathrm{N}$, and $N /$ minuta $-\mathrm{N}$ algae

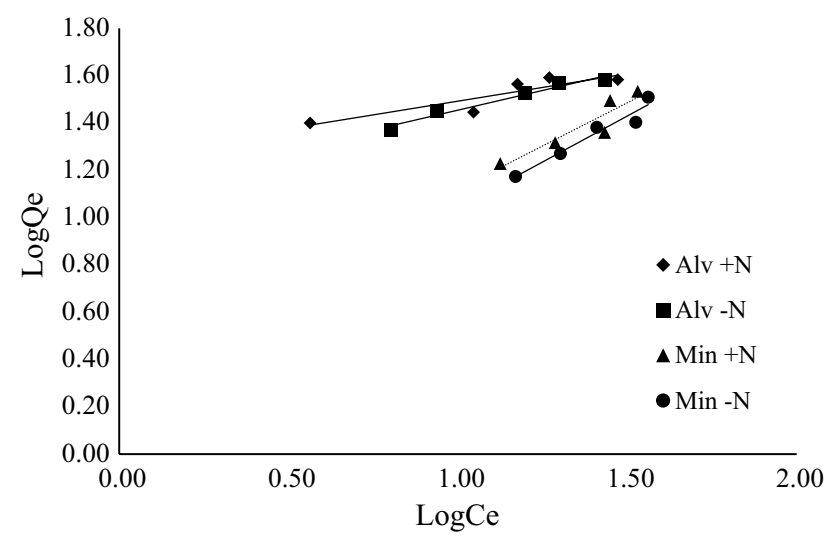

Fig. 13 Freundlich isotherm for zinc ions onto $N$. alveolaris $+\mathrm{N}, N$. alveolaris $-\mathrm{N}, N$. minuta $+\mathrm{N}$, and $\mathrm{N} /$ minuta $-\mathrm{N}$ algae

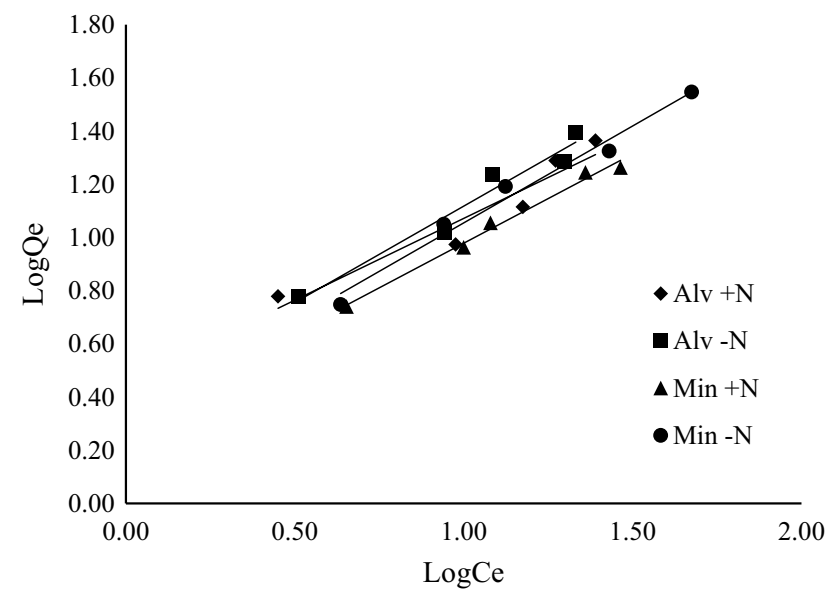

Fig. 14 Freundlich isotherm for copper ions onto $N$. alveolaris $+\mathrm{N}$, $N$. alveolaris $-\mathrm{N}, N$. minuta $+\mathrm{N}$, and $N /$ minuta $-\mathrm{N}$ algae

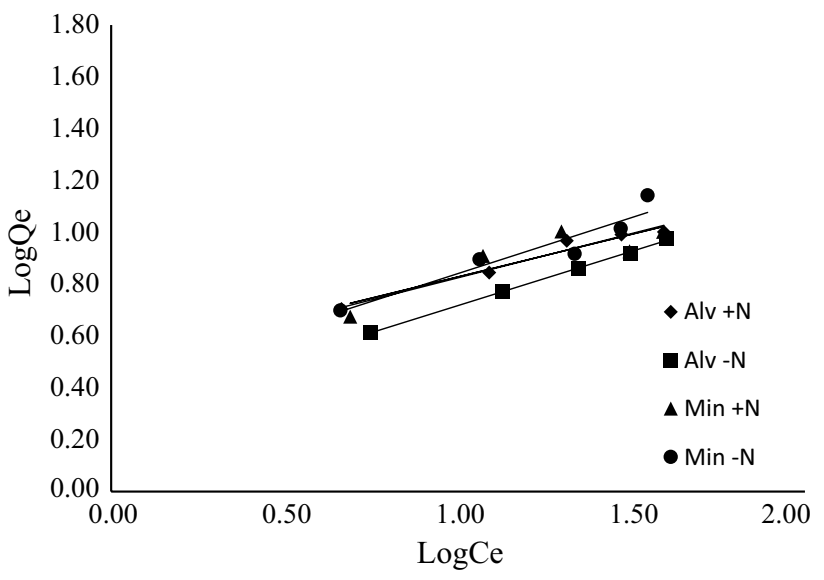

Fig. 15 Freundlich isotherm for nickel ions onto $N$. alveolaris $+\mathrm{N}, N$. alveolaris $-\mathrm{N}, N$. minuta $+\mathrm{N}$, and $N /$ minuta $-\mathrm{N}$ algae

show adsorption isotherms of the four algae type by linear analysis. Table 3 summarizes the corresponding isotherm parameters and their correlation coefficients $\left(R^{2}\right)$ for each parameter. The $R^{2}$ values that fitted the Langmuir isotherms were $0.869-0.998$ and the ones fitted the Freundlich isotherms were 0.805-0.997. The data indicated that the Langmuir isotherm model was the best fit to the adsorption processes since it had a higher regression coefficient $\left(R^{2}\right)$. The Langmuir isotherm model assumes a monolayer adsorption of the metal ions onto the algae surface containing a finite number of identical adsorption sites that are energetically equivalent and once these finite adsorption sites are filled, no further adsorption can take place (Hameed 2007). Since the $R_{\mathrm{L}}$ values for the Langmuir isotherms ranged $0.067-0.458$ $\left(0<R_{\mathrm{L}}<1\right)$ the adsorption mechanisms are said to form a monolayer on the algae surface. The Freundlich isotherms indicate that the adsorption is a physical process since the values ranged 1.23-4.31 $(n>1)$.

Table 3 shows the values of $q_{\max }$ and $K_{\mathrm{L}}(\mathrm{L} / \mathrm{mg})$ obtained from Langmuir isotherms for the biosorption values of the five heavy metals per algae. Again, $q_{\max }$ is the biosorption capacity, or amount of metal algae can bind, and $K_{\mathrm{L}}$ is the Langmuir isotherm constant, which represents the affinity of each algae for the different metal cations (the lower the value of $K_{\mathrm{L}}$ the higher the affinity). The maximum adsorption capacities match very well with the high affinity of biosorption of the metals by the algae shown in Table 3 and highlighted in bold. The higher the affinity (low $\mathrm{K}_{\mathrm{L}}$ ) of biosorption, the larger the maximum adsorption capacity $\left(q_{\max }\right)$ of the algae for the specific metal ion, which is the best-case scenario. $N$. alveolaris $-\mathrm{N}$ had an increase of $q_{\max }$ and $\mathrm{K}_{\mathrm{L}}$ for $\mathrm{Zn}^{2+}$ and $\mathrm{Cu}^{2+}$ and a decrease for $\mathrm{Cd}^{2+}$ and $\mathrm{Ni}^{2+}$. On the other hand, N. minuta $-\mathrm{N}$ had an increase of $q_{\max }$ and $K_{\mathrm{L}}$ for all metals except $\mathrm{Pb}^{2+}$. This may be related to the degree of affinity of a specific biomass for each metal. 
Fig. 16 a) Bar graphs of the Langmuir isotherm biosorption capacities $\left(\mathrm{q}_{\max }\right)$ of five metal ions for Neochloris alveolaris $+\mathrm{N}(A l v+\mathrm{N})$, Neochloris alveolaris $-\mathrm{N}(A l v-\mathrm{N})$, Neochloris minuta $+\mathrm{N}(\operatorname{Min}+\mathrm{N})$, and Neochloris minuta $-\mathrm{N}($ Min $-\mathrm{N})$ and b) biomass composition (lipid, starch, and protein) after 10 days of growth of Neochloris alveolaris $+\mathrm{N}(A l v+\mathrm{N})$, Neochloris alveolaris $-\mathrm{N}(A l v$ $-\mathrm{N})$, Neochloris minuta $+\mathrm{N}$ $(M i n+\mathrm{N})$, and Neochloris minuta $-\mathrm{N}($ Min $-\mathrm{N})$ (a)

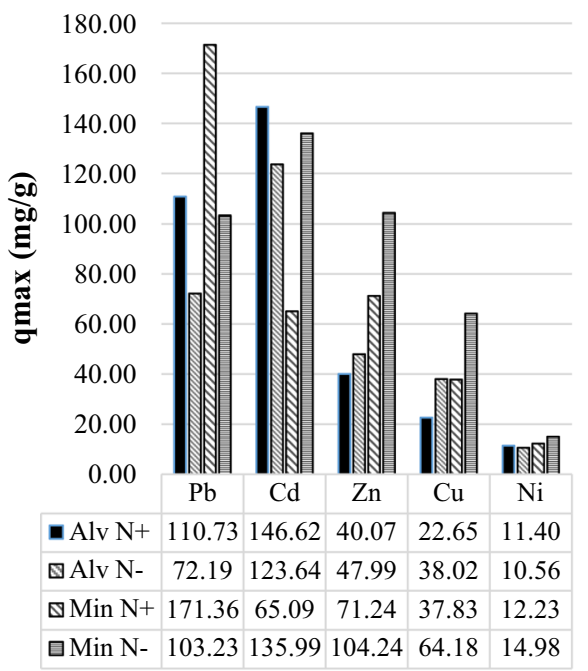

Divalent Metal Ions

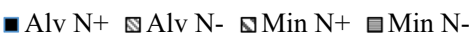

(b)

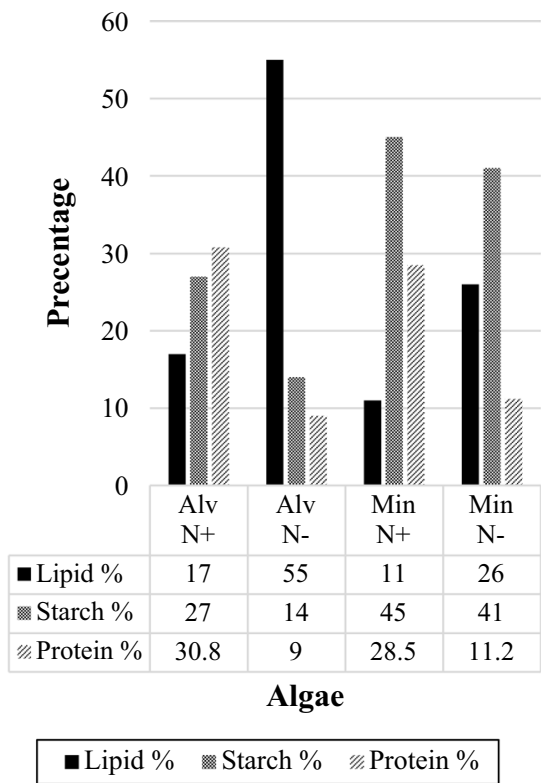

Table 3 The Langmuir and Freundlich isotherm data for five heavy metals tested with each algae: Neochloris alveolaris $+\mathrm{N}(A l v+\mathrm{N})$, Neochloris alveolaris $-\mathrm{N}$ (Alv $-\mathrm{N})$, Neochloris minuta $+\mathrm{N}$ $($ Min $+\mathrm{N})$, and Neochloris minuta $-\mathrm{N}($ Min $-\mathrm{N})$

\begin{tabular}{|c|c|c|c|c|c|c|c|}
\hline \multirow[t]{2}{*}{ Metal and Algae } & \multicolumn{4}{|c|}{ Langmuir Isotherm Data } & \multicolumn{3}{|c|}{ Freundlich Isotherm Data } \\
\hline & $\mathbf{R}^{2}$ & $\mathbf{q}_{\max }(\mathrm{mg} / \mathrm{g})$ & $\mathbf{K}_{\mathbf{L}}(\mathrm{L} / \mathrm{mg})$ & $\mathbf{R}^{2}$ & $\mathbf{R}^{2}$ & $\mathbf{n}$ & $\mathbf{K}_{\mathbf{f}}(\mathrm{mg} / \mathrm{g})$ \\
\hline \multicolumn{8}{|l|}{$\mathbf{P b}$} \\
\hline $\mathrm{Alv}+\mathrm{N}$ & 0.947 & 110.73 & 0.106 & 0.137 & 0.956 & 2.79 & 22.93 \\
\hline Alv -N & 0.976 & 72.19 & 0.056 & 0.209 & 0.997 & 3.30 & 14.87 \\
\hline $\operatorname{Min}+\mathrm{N}$ & 0.972 & 171.36 & 0.028 & 0.296 & 0.886 & 2.25 & 15.67 \\
\hline Min -N & 0.979 & 103.23 & 0.072 & 0.178 & 0.935 & 2.83 & 19.23 \\
\hline \multicolumn{8}{|l|}{ Cd } \\
\hline $\mathrm{Alv}+\mathrm{N}$ & 0.998 & 146.62 & 0.009 & 0.458 & 0.985 & 1.23 & 1.92 \\
\hline Alv $-\mathrm{N}$ & 0.979 & 123.64 & 0.017 & 0.426 & 0.954 & 1.41 & 3.65 \\
\hline $\operatorname{Min}+\mathrm{N}$ & 0.980 & 65.09 & 0.070 & 0.294 & 0.874 & 2.27 & 9.23 \\
\hline Min -N & 0.897 & 135.99 & 0.011 & 0.450 & 0.820 & 1.61 & 3.76 \\
\hline \multicolumn{8}{|l|}{ Zn } \\
\hline $\mathrm{Alv}+\mathrm{N}$ & 0.750 & 40.07 & 0.431 & 0.067 & 0.805 & 4.31 & 18.20 \\
\hline Alv -N & 0.992 & 47.99 & 0.155 & 0.151 & 0.963 & 3.00 & 13.21 \\
\hline $\operatorname{Min}+\mathrm{N}$ & 0.869 & 71.24 & 0.023 & 0.373 & 0.858 & 1.37 & 2.46 \\
\hline Min -N & 0.966 & 104.24 & 0.011 & 0.427 & 0.945 & 1.29 & 1.84 \\
\hline \multicolumn{8}{|l|}{$\mathbf{C u}$} \\
\hline $\mathrm{Alv}+\mathrm{N}$ & 0.893 & 22.65 & 0.123 & 0.310 & 0.918 & 1.63 & 2.86 \\
\hline Alv -N & 0.964 & 38.02 & 0.056 & 0.391 & 0.957 & 1.38 & 2.47 \\
\hline $\mathrm{Min}+\mathrm{N}$ & 0.916 & 37.83 & 0.038 & 0.420 & 0.792 & 1.60 & 2.43 \\
\hline Min -N & 0.991 & 64.18 & 0.023 & 0.449 & 0.960 & 1.37 & 2.12 \\
\hline \multicolumn{8}{|l|}{$\mathbf{N i}$} \\
\hline $\mathrm{Alv}+\mathrm{N}$ & 0.969 & 11.40 & 0.134 & 0.271 & 0.967 & 2.93 & 3.04 \\
\hline Alv -N & 0.977 & 10.56 & 0.169 & 0.322 & 0.998 & 2.39 & 1.99 \\
\hline $\operatorname{Min}+\mathrm{N}$ & 0.932 & 12.23 & 0.115 & 0.300 & 0.775 & 3.05 & 3.16 \\
\hline Min $-\mathrm{N}$ & 0.918 & 14.98 & 0.111 & 0.318 & 0.900 & 2.32 & 2.42 \\
\hline
\end{tabular}


The total amount of metal attached to its surface will also depend on the number of active sites and how easily they can be accessed (Romera et al. 2007). Maximum adsorption of a metal ion by a biosorbent would help if maximum recovery of metal ions were the priority even if the affinity is low. Ideally, both maximum adsorption and high affinity would be the best-case scenario, if the recovery of large amounts of metals while achieving low equilibrium concentrations at the same time were of the highest importance. The only time when the $\mathrm{q}_{\max }$ and the affinity $\left(K_{\mathrm{L}}\right)$ did not improve simultaneously occurred between $N$. alveolaris $-\mathrm{N}$ and $\mathrm{Pb}^{2+}$, where the $\mathrm{q}_{\max }$ decreased but the affinity increased $\left(K_{\mathrm{L}}\right.$ was smaller).

\section{Chemical composition and metal ion influence on biosorption capacities}

The chemical composition of the algae can play an important role in heavy metal biosorption. Microalgae biosorb by two main mechanisms: (i) ion exchange wherein ions (such as $\mathrm{Na}^{+}, \mathrm{Mg}^{2+}$, and $\mathrm{Ca}^{2+}$ ) become displaced by heavy metal ions, and (ii) complexation between metal ions and various functional groups (Abbas 2014). For our case, we focus on the complexation of the metal ions with functional groups based on the composition of the algae. The mechanism of biosorption is based on the number of metal-binding processes taking place with components of the algae's cell wall. The algae cell walls can reversibly biosorb metals, functioning in a similar way to an ion-exchange resin. Thus, the biosorption mechanism can be considered as being dependent on the composition of the algal cell wall (Abbas 2014). As the algae lipid, protein, and starch content changes in the absence of nitrogen, its surface functional groups also change. It has been suggested that these biomolecules that are distributed on the cell wall surface of algal biomass assist with binding (Rangbhashiyam 2019) so changing the surface functional groups could change the biosorption capacities of the algae.

Based on the Langmuir isotherm constants (Table 3) and the biomass composition of the algae (Figs. 16a, b), the algae grown in nitrogen $(+\mathrm{N})$ gave the largest biosorption capacities $\left(\mathrm{q}_{\max }\right)$ for lead (N. minuta and $N$. alveolaris) and cadmium ( $N$. alveolaris), while the nitrogen-depleted $(-\mathrm{N})$ algae did the same for zinc, copper, and nickel (N. minuta only). The $+\mathrm{N}$ algae had a higher protein content when compared to their $-\mathrm{N}$ counterparts, with $N$. alveolaris having the greatest protein content $(30.8 \pm 0.2 \%)$, while nitrogendepleted $(-\mathrm{N})$ algae had a higher lipid content (more than doubled). These modifications to the composition of algae influenced the absorption capacity of the metals.

The Pearson theory of Hard and Soft, Acid and Bases (HSAB) is a theory that can predict significant degree of selectivity that occurs in acids (such as metal ions) and bases (such as functional groups) interactions (Pearson 1990). Based on this concept, metal ions and reactive molecules such as the functional groups are assessed on the basis of their respective polarizability in such manner, that acids (electrophiles) and bases (nucleophiles) are classified as either soft (relatively polarizable) or hard (relatively nonpolarizable). Hard acids are small and highly charged metal ions while soft acids are larger and more polarizable than lower charged metal ions. Hard bases contain smaller, less polarizable donor atoms like oxygen or nitrogen and soft bases contain larger, more polarizable donor atoms, such as sulfur or phosphorus. Based on HSAB theory, $\mathrm{Cd}^{2+}$ is considered a soft metal ion acid and $\mathrm{Pb}^{2+}, \mathrm{Zn}^{2+}, \mathrm{Cu}^{2+}$, and $\mathrm{Ni}^{2+}$ are considered borderline hard/soft metal ion acids, Table 4. $\mathrm{Pb}^{2+}$ is well known to interact with both soft (sulfur based) and hard (oxygen based) molecules, creating compounds like anglesite $\left(\mathrm{PbSO}_{4}\right)$ and cerussite $\left(\mathrm{PbCO}_{3}\right)$, with a preference for soft [i.e., the well-known and abundant galena $(\mathrm{PbS})$ ] (Pearson 1990). Algal proteins contain functional groups such as alcohols, thiols, thioethers, amides, and carboxylic acids. The presence of thiols and thioethers in the proteins would make them soft bases that would preferentially bind with soft metals such as $\mathrm{Cd}^{2+}$ and $\mathrm{Pb}^{2+}$. On the other hand, hydroxyl and acetal functional groups of starch and carboxyl groups of lipids are considered hard bases and would bind with hard acids.

Based on this theory, we anticipated that the softer metal ions $\mathrm{Pb}^{2+}$ and $\mathrm{Cd}^{2+}$, which are also the lager metal ions, should prefer a higher protein content alga, $+\mathrm{N}$ (softer bases), and indeed the data shows that $N$. minuta $+\mathrm{N}$ biosorbed the greatest amount of $\mathrm{Pb}^{2+}\left(q_{\max }=171.36 \mathrm{mg} / \mathrm{g}\right)$ and $N$. alveolaris $+\mathrm{N}$ biosorbs the greatest amount of $\mathrm{Cd}^{2+}$ $\left(q_{\max }=146.62 \mathrm{mg} / \mathrm{g}\right)$. To explain the high biosorption of lead, it has been well documented that anionic polysaccharides that are distributed widely in the cell walls of brown and green algae have a high affinity for $\mathrm{Pb}^{2+}$ ions (Romera et al. 2007). This could be due to the ion-exchange mechanism rather than the complexion between metal ions and various functional groups. Interestingly, $N$. minuta $+\mathrm{N}$ has

Table 4 Crystal and effective ionic radii of 6-coordinate ions(Shannon 1976) and Hard and Soft, Acid and Bases (HSAB) Pearson theory of the metal ions

\begin{tabular}{llll}
\hline Metal Ion & $\begin{array}{l}\text { Crystal ionic } \\
\text { radii }(\mathrm{pm})\end{array}$ & $\begin{array}{l}\text { Effective ionic } \\
\text { radii }(\mathrm{pm})\end{array}$ & HSAB \\
\hline $\mathrm{Pb}^{2+}$ & 133 & 119 & $\begin{array}{c}\text { Borderline } \\
\text { (soft and } \\
\text { hard) }\end{array}$ \\
$\mathrm{Cd}^{2+}$ & 109 & 95 & Soft \\
$\mathrm{Zn}^{2+}$ & 88 & 74 & Borderline \\
$\mathrm{Cu}^{2+}$ & 87 & 73 & Borderline \\
$\mathrm{Ni}^{2+}$ & 83 & 69 & Borderline \\
\hline
\end{tabular}


the most starch (hard base) and adsorbed $\mathrm{Cd}^{2+}$ (soft acid) the least, which follows the HSAB theory.

For the harder metal ions, the HSAB theory leads us to predict borderline hard/soft acids $\left(\mathrm{Zn}^{2+}, \mathrm{Cu}^{2+}\right.$, and $\left.\mathrm{Ni}^{2+}\right)$ should prefer a higher starch and lipid content present in $-\mathrm{N}$ algae (harder bases) and in fact they did. $N$. minuta $-\mathrm{N}$ gave the highest $\mathrm{q}_{\max }$ for $\mathrm{Zn}^{2+}(104.24 \mathrm{mg} / \mathrm{g}), \mathrm{Cu}^{2+}(64.18 \mathrm{mg} / \mathrm{g})$, and $\mathrm{Ni}^{2+}(14.98 \mathrm{mg} / \mathrm{g})$. N. minuta species had the greatest amount of starch (nearly double that of $N$. alveolaris) and when coupled with higher lipid content from growing the algae in a nitrogen-depleted (-N) environment, it resulted in high biosorption capacities for the hard metal acids.

To evaluate the results, the sorption capacities of each algae $\left(\mathrm{q}_{\max }\right)$ were measured and organized in decreasing order of $\mathrm{q}_{\max }$ for each alga, Table 5:

N. alveolaris $+\mathrm{N}: \mathrm{Cd}^{2+}>\mathrm{Pb}^{2+}>\mathrm{Zn}^{2+}>\mathrm{Cu}^{2+}>\mathrm{Ni}^{2+}$

$N$. alveolaris $-\mathrm{N} \mathrm{Cd}^{2+}>\mathrm{Pb}^{2+}>\mathrm{Zn}^{2+}>\mathrm{Cu}^{2+}>\mathrm{Ni}^{2+}$

The metal sequence is identical for both $N$. alveolaris $+\mathrm{N}$ and $-\mathrm{N}$ species. In this instance, the amounts of lipids, proteins and carbohydrates did not change the sequence of metal sorption capacity (in decreasing order); however, N. alveolaris $-\mathrm{N}$ was able to increase the biosorption capacity of $\mathrm{Zn}^{2+}$ and $\mathrm{Cu}^{2+}$ and decrease the capacity of $\mathrm{Pb}^{2+}, \mathrm{Cd}^{2+}$, and $\mathrm{Ni}^{2+}$.

N. minuta $+\mathrm{N}: \mathrm{Pb}^{2+}>\mathrm{Zn}^{2+}>\mathrm{Cd}^{2+}>\mathrm{Cu}^{2+}>\mathrm{Ni}^{2+}$

N. minuta-N: $\mathrm{Cd}^{2+}>\mathrm{Zn}^{2+}>\mathrm{Pb}^{2+}>\mathrm{Cu}^{2+}>\mathrm{Ni}^{2+}$

For $N$. minuta the metal sequence is identical for $\mathrm{Zn}^{2+}$, $\mathrm{Cu}^{2+}$, and $\mathrm{Ni}^{2+}$, which are all borderline hard/soft acids, so the composition of the specific algae does not affect the relative biosorption of these metals. However, there is a noticeable difference in the sorption capacity for $\mathrm{Pb}^{2+}$ and $\mathrm{Cd}^{2+}$. $\mathrm{Pb}^{2+}$, which can bind to both hard and soft bases, binds better with $N$. minuta $+\mathrm{N}$, which contains significantly more proteins, more starch, and much less lipids. $\mathrm{Cd}^{2+}$, which is a softer acid than lead, unexpectedly adsorbed better with $N$. minuta $-\mathrm{N}$. Based on the HSAB theory, it should have adsorbed better onto $N$. minuta $+\mathrm{N}$ because it contains higher levels of soft proteins, but it did not.

When comparing the biosorption capacities between the two type of algae, $N$. minuta had the highest values for four out of the five metals $\left(\mathrm{Pb}^{2+}, \mathrm{Zn}^{2+}, \mathrm{Cu}^{2+}\right.$, and $\left.\mathrm{Ni}^{2+}\right)$, Table 5, while $N$. alveolaris adsorbed the most $\mathrm{Cd}^{2+}$. This may be

Table 5 Langmuir isotherm biosorption capacities of five metal ions $\left(\mathrm{q}_{\max }, \mathrm{mg} / \mathrm{g}\right)$ for the algae: Neochloris alveolaris $+\mathrm{N}($ Alv $+\mathrm{N})$, Neochloris alveolaris $-\mathrm{N}(A l v-\mathrm{N})$, Neochloris minuta $+\mathrm{N}(M i n+\mathrm{N})$, and Neochloris minuta $-\mathrm{N}$ (Min $-\mathrm{N})$

\begin{tabular}{lrrrr}
\hline Metal & Alv $+\mathrm{N}$ & Alv $-\mathrm{N}$ & Min $+\mathrm{N}$ & Min $-\mathrm{N}$ \\
\hline $\mathrm{Pb}$ & 110.73 & 72.19 & 171.36 & 103.23 \\
$\mathrm{Cd}$ & 146.62 & 123.64 & 65.09 & 135.99 \\
$\mathrm{Zn}$ & 40.07 & 47.99 & 71.24 & 104.24 \\
$\mathrm{Cu}$ & 22.65 & 38.02 & 37.83 & 64.18 \\
$\mathrm{Ni}$ & 11.40 & 10.56 & 12.23 & 14.98 \\
\hline
\end{tabular}

due to $\mathrm{Cd}^{2+}$ being the softest acid of the five metal ions and preferred the algae with the highest protein composition $(N$. alveolaris $+\mathrm{N}$ ).

These results indicate the type of algae species ( $N$. minuta vs. $N$. alveolaris) have significant effects on the biosorption capacities but the composition of the algae $(+\mathrm{N}$ versus $-\mathrm{N})$ also plays a role for $\mathrm{Pb}^{2+}$ and $\mathrm{Cd}^{2+}$, which are both larger and more polarizable ions.

When algae are placed in waters that are contaminated with heavy metals their biosorption capacities will depend on the species of the algae and the nitrogen content in the water. For both $N$. alveolaris and N. minuta, nitrogen deprivation increased the biosorption capacities for $\mathrm{Zn}^{2+}$ and $\mathrm{Cu}^{2+}$ but decreased it for $\mathrm{Pb}^{2+}$. In the cases for $\mathrm{Cd}^{2+}$ and $\mathrm{Ni}^{2+}$, the biosorption capacities decreased for $N$. alveolaris -N and increased for $N$. minuta $-\mathrm{N}$ compared to the nitrogenrich species. As algae grow in metal-contaminated waters, the nitrogen content will be consumed and start decreasing causing a change to the biomass composition. As a result, these biomass composition changes so will impact the biosorption capacity and adsorption efficiency.

\section{Comparison of biosorption capacities}

The maximum adsorption capacities $q_{\max }$ (mg metal/g algal) of $N$. minuta and $N$. alveolaris ranged $\mathrm{Pb}^{2+}$ $72.19-171.36 \mathrm{mg} / \mathrm{g}, \mathrm{Cd}^{2+} 65.09-146.62 \mathrm{mg} / \mathrm{g}, \mathrm{Zn}^{2+}$ $40.07-104.24 \mathrm{mg} / \mathrm{g}, \mathrm{Cu}^{2+} 22.65-64.18 \mathrm{mg} / \mathrm{g}$, and $\mathrm{Ni}^{2+}$ $10.56-14.98 \mathrm{mg} / \mathrm{g}$, Table 5. Literature $\mathrm{q}_{\max }$ values of other green algal cell species for the same metals, Table 6 , ranged $\mathrm{Pb}^{2+} 26.9-131.36 \mathrm{mg} / \mathrm{g}(253.6 \mathrm{mg} / \mathrm{g}$ when the algae was immobilized on alginate beads), $\mathrm{Cd}^{2+} 0.7-88.8 \mathrm{mg} / \mathrm{g}$, $\mathrm{Zn}^{2+} 1.3-43.43 \mathrm{mg} / \mathrm{g}, \mathrm{Cu}^{2+} 14.6-114.4 \mathrm{mg} / \mathrm{g}$, and $\mathrm{Ni}^{2+}$ $12.03-59.69 \mathrm{mg} / \mathrm{g}$. When comparing with literature values of both N. minuta and N. alveolaris, our results agree with previously reported values for all of the metals, such that lead has the highest and nickel the lowest adsorption capacities. However, this work achieved adsorption capacities that exceeded reported values for $\mathrm{Cd}^{2+}, \mathrm{Zn}^{2+}$, and $\mathrm{Pb}^{2+}$, but were lower than reported for $\mathrm{Ni}^{2+}$.

Both species of algae had high adsorption capacities for $\mathrm{Cd}^{2+}\left(N\right.$. alveolaris being favored) and $\mathrm{Zn}^{2+}(N$. minuta being favored). It is evident that the species of the algae favor different metal ions. This might be due to the size of the metal ions and/or their polarizabilities favoring the specific algae binding sites. The $\mathrm{Pb}^{2+} \mathrm{q}_{\max }$ values are higher than previously reported ranges for green algae, but it seems that $N$. minuta $+\mathrm{N}$ was highly favored, with preference for both the $+\mathrm{N}$ species that contained higher amounts of proteins. The biosorption capacities of both algae for $\mathrm{Cu}^{2+}$ are in the range of the literature values with $N$. minuta $-\mathrm{N}$ being favored. Both algae species adsorb $\mathrm{Ni}^{2+}$ poorly and are in the low range of the literature values. 
Table 6 Sorption parameters in monometallic systems for a number of green algae

\begin{tabular}{|c|c|c|c|c|c|c|}
\hline Metal Ions & Species of Algae & $\mathrm{pH}$ & Eq. Time (min) & $\mathrm{q}_{\max }(\mathrm{mmol} / \mathrm{g})$ & $\mathrm{q}_{\max }(\mathrm{mg} / \mathrm{g})$ & References \\
\hline \multirow[t]{29}{*}{$\mathbf{P b}(\mathbf{I I})$} & Ulva lactuca & 4.5 & - & 0.61 & 126.4 & (Jinsong He 2014) \\
\hline & Cladophora glomerata & 4.5 & - & 0.35 & 72.5 & (Jinsong He 2014) \\
\hline & Ulva sp. & 5.0 & - & 1.46 & 302.5 & (Jinsong He 2014) \\
\hline & Codium vermilara & 5.0 & - & 0.30 & 62.2 & (Jinsong He 2014) \\
\hline & Spirogyra insignis & 5.0 & - & 0.24 & 49.7 & (Jinsong He 2014) \\
\hline & Spirogyra neglecta & 5.0 & 60 & 0.56 & 116.0 & (Jinsong He 2014) \\
\hline & Caulerpa lentillifera & 5.0 & - & 0.13 & 26.9 & (Jinsong He 2014) \\
\hline & Spirogyra sp. & 5.0 & - & 0.43 & 89.1 & (Jinsong He 2014) \\
\hline & Cladophora sp. & 5.0 & - & 0.22 & 45.6 & (Jinsong He 2014) \\
\hline & Spirogyra sp. & 5.0 & - & 0.46 & 94.3 & (Matei et al. 2015) \\
\hline & Caulerpa lentillifera & 5.0 & 30 & 1.07 & 28.98 & (Monika et al. 2014) \\
\hline & Chlamydomonas reinhardtii & 6.0 & 60 & 0.47 & 97.38 & (Monika et al. 2014) \\
\hline & Chlorella vulgaris & 5.0 & - & 0.63 & 131.36 & (Monika et al. 2014) \\
\hline & Cladophora glomerata & 4.5 & 180 & 0.35 & 73.50 & (Monika et al. 2014) \\
\hline & Microcystis novacekii & 5.0 & 240 & 0.39 & 80.00 & (Monika et al. 2014) \\
\hline & Ulva lactuca & 4.5 & 30 & 0.61 & 126.50 & (Monika et al. 2014) \\
\hline & Spirogyra insignis & 5 & 120 & 0.25 & 51.5 & (Romera et al. 2007) \\
\hline & Codium vermilara & 5 & 120 & 0.30 & 63.3 & (Romera et al. 2007) \\
\hline & Scenedesmus quadricauda & 6 & 10 & 0.14 & 28.36 & (K1zılkaya et al. 2012) \\
\hline & Neochloris pseudoalveolaris & 6 & 10 & 0.14 & 28.67 & (K1zılkaya et al. 2012) \\
\hline & Chlamydomonas reinhardtii & 5 & 60 & 1.22 & 253.6 & (Bilal 2018) \\
\hline & Ulva lactuca & 5 & 60 & 0.17 & 34.7 & (Bilal 2018) \\
\hline & Chlorella vulgaris & 4 & - & 0.47 & 97.38 & (Romera et al. 2006) \\
\hline & C. fasicularis & - & 120 & 0.151 & 31.250 & (Nirmal Kumar et al. 2009) \\
\hline & U. lactuca & - & 120 & 0.142 & 29.412 & (Nirmal Kumar et al. 2009) \\
\hline & Chaetomorpha sp. & - & 120 & 0.179 & 37.037 & (Nirmal Kumar et al. 2009) \\
\hline & C. sertularioides & - & 120 & 0.103 & 21.277 & (Nirmal Kumar et al. 2009) \\
\hline & V. pachynema & - & 120 & 0.402 & 83.333 & (Nirmal Kumar et al. 2009) \\
\hline & C. vulgaris & $5-6$ & 30 & 0.47 & 97.384 & (Klimmek et al. 2001) \\
\hline \multirow[t]{20}{*}{$\mathbf{C u}(\mathrm{II})$} & Ulva sp. & 5.0 & - & 0.75 & 47.7 & (Jinsong He 2014) \\
\hline & Codium vermilara & 5.0 & - & 0.26 & 16.5 & (Jinsong He 2014) \\
\hline & Spirogyra insignis & 4.0 & - & 0.30 & 19.1 & (Jinsong He 2014) \\
\hline & Spirogyra neglecta & 4.5 & 60 & 1.80 & 114.4 & (Jinsong He 2014) \\
\hline & Ulva fasciata & 5.5 & - & 1.14 & 72.4 & (Jinsong He 2014) \\
\hline & Ulva fasciata & 5.0 & - & 0.42 & 26.7 & (Jinsong He 2014) \\
\hline & Caulerpa lentillifera & 5.0 & - & 0.08 & 5.1 & (Jinsong He 2014) \\
\hline & Spirogyra sp. & 5.0 & - & 0.60 & 38.1 & (Jinsong He 2014) \\
\hline & Cladophora sp. & 5.0 & - & 0.23 & 14.6 & (Jinsong He 2014) \\
\hline & Spirogyra sp. & 5.0 & - & 0.53 & 33.7 & (Jinsong He 2014) \\
\hline & Spirogyra sp. & 5.9 & - & 0.56 & 35.6 & (Matei et al. 2015) \\
\hline & Caulerpa lentillifera & 5.0 & 30 & 0.13 & 8.26 & (Monika et al. 2014) \\
\hline & Chlorella vulgaris & 5.0 & 15 & 0.93 & 58.80 & (Monika et al. 2014) \\
\hline & Codium vermilara & 5 & 120 & 0.27 & 16.9 & (Romera et al. 2007) \\
\hline & Spirogyra insignis & 4 & 120 & 0.30 & 19.3 & (Romera et al. 2007) \\
\hline & Ulva fasciata & 6 & 180 & 1.16 & 73.5 & (Bilal 2018) \\
\hline & Chlorella vulgaris & 6 & - & 0.295 & 18.75 & (Romera et al. 2006) \\
\hline & Chlorella vulgaris & 2 & - & 0.254 & 16.14 & (Romera et al. 2006) \\
\hline & Chlorella vulgaris & 4 & - & 0.549 & 34.89 & (Romera et al. 2006) \\
\hline & Chlorella vulgaris & 4.5 & - & 0.758 & 48.17 & (Romera et al. 2006) \\
\hline Cd(II) & Ulva sp. & 5.5 & - & 0.58 & 65.2 & (Jinsong He 2014) \\
\hline
\end{tabular}


Table 6 (continued)

\begin{tabular}{|c|c|c|c|c|c|c|}
\hline Metal Ions & Species of Algae & $\mathrm{pH}$ & Eq. Time (min) & $\mathrm{q}_{\max }(\mathrm{mmol} / \mathrm{g})$ & $\mathrm{q}_{\max }(\mathrm{mg} / \mathrm{g})$ & References \\
\hline & Chaetomorpha linum & 5.0 & - & 0.48 & 54.0 & (Jinsong He 2014) \\
\hline & Codium vermilara & 6.0 & - & 0.19 & 21.4 & (Jinsong He 2014) \\
\hline & Spirogyra insignis & 6.0 & - & 0.20 & 22.5 & (Jinsong He 2014) \\
\hline & Ulva lactuca & 5.0 & - & 0.25 & 28.1 & (Jinsong He 2014) \\
\hline & Oedogonium sp. & 5.0 & - & 0.79 & 88.8 & (Jinsong He 2014) \\
\hline & Caulerpa lentillifera & 5.5 & - & 0.04 & 4.5 & (Jinsong He 2014) \\
\hline & Spirogyra sp. & - & - & 0.006 & 0.7 & (Jinsong He 2014) \\
\hline & Spirogyra sp. & 5.5 & - & 0.20 & 22.5 & (Matei et al. 2015) \\
\hline & Caulerpa lentillifera & 5.0 & 30 & 0.042 & 4.70 & (Monika et al. 2014) \\
\hline & Chaetomorpha linum & 5.0 & 24 & 0.48 & 53.75 & (Monika et al. 2014) \\
\hline & Chlamydomonas reinhardtii & 5.0 & 60 & 0.38 & 42.71 & (Monika et al. 2014) \\
\hline & Chlorella vulgaris & 4.0 & 1440 & 0.77 & 86.60 & (Monika et al. 2014) \\
\hline & Caulerpa lentillifera & 5.0 & 30 & 0.042 & 4.70 & (Monika et al. 2014) \\
\hline & Spirogyra insignis & 6 & 120 & 0.20 & 22.9 & (Romera et al. 2007) \\
\hline & Codium vermilara & 6 & 120 & 0.19 & 21.8 & (Romera et al. 2007) \\
\hline & Scenedesmus quadricauda & 6 & 10 & 0.22 & 24.37 & (Kızılkaya et al. 2012) \\
\hline & Neochloris pseudoalveolaris & 6 & 10 & 0.25 & 27.58 & (K1zılkaya et al. 2012) \\
\hline & Chlorella vulgaris (live) & 5 & 105 & 0.15 & 16.34 & (Bilal 2018) \\
\hline & Chlorella vulgaris (dead) & 5 & 105 & 0.15 & 16.65 & (Bilal 2018) \\
\hline & Ulva lactuca & 5 & 60 & 0.26 & 29.2 & (Bilal 2018) \\
\hline & Chlamydomonas reinhardtii & - & - & 0.59 & 66.5 & (Bilal 2018) \\
\hline & Chlorella vulgaris $(G)$ & 4 & - & 0.30 & 33.72 & (Romera et al. 2006) \\
\hline & C. fasicularis & - & 120 & 0.041 & 4.587 & (Nirmal Kumar et al. 2009) \\
\hline & U. lactuca & - & 120 & 0.074 & 8.264 & (Nirmal Kumar et al. 2009) \\
\hline & Chaetomorpha sp. & - & 120 & 0.182 & 20.408 & (Nirmal Kumar et al. 2009) \\
\hline & C. sertularioides & - & 120 & 0.024 & 2.667 & (Nirmal Kumar et al. 2009) \\
\hline & V. pachynema & - & 120 & 0.168 & 18.868 & (Nirmal Kumar et al. 2009) \\
\hline & C. vulgaris & $5-6$ & 30 & 0.30 & 33.723 & (Klimmek et al. 2001) \\
\hline \multirow[t]{11}{*}{$\mathbf{Z n}(\mathrm{II})$} & Ulva sp. & 5.5 & - & 0.54 & 35.3 & (Jinsong He 2014) \\
\hline & Codium vermilara & 6.0 & - & 0.36 & 23.5 & (Jinsong He 2014) \\
\hline & Spirogyra insignis & 6.0 & - & 0.32 & 20.9 & (Jinsong He 2014) \\
\hline & Caulerpa lentillifera & 5.0 & - & 0.04 & 2.6 & (Jinsong He 2014) \\
\hline & Spirogyra sp. & - & - & 0.02 & 1.3 & (Jinsong He 2014) \\
\hline & Caulerpa lentillifera & 5.0 & 30 & 0.041 & 2.66 & (Monika et al. 2014) \\
\hline & Chlorella vulgaris & 5.0 & - & 0.66 & 43.43 & (Monika et al. 2014) \\
\hline & Spirogyra insignis & 6 & 120 & 0.32 & 21.1 & (Romera et al. 2007) \\
\hline & Codium vermilara & 6 & 120 & 0.36 & 23.8 & (Romera et al. 2007) \\
\hline & Ulva sp. & 5.5 & 120 & 0.45 & 29.63 & (Bilal 2018) \\
\hline & Chlorella vulgaris & 4 & - & 0.37 & 24.19 & $\begin{array}{l}\text { (Romera et al. 2006) (Klimmek } \\
\text { et al. 2001) }\end{array}$ \\
\hline \multirow[t]{9}{*}{$\mathbf{N i}(\mathbf{I I})$} & Ulva sp. & 5.5 & - & 0.29 & 17.0 & (Jinsong He 2014) \\
\hline & Codium vermilara & 6.0 & - & 0.22 & 12.9 & (Jinsong He 2014) \\
\hline & Spirogyra insignis & 6.0 & - & 0.29 & 17.0 & (Jinsong He 2014) \\
\hline & Ulva lactuca & 4.5 & - & 1.14 & 66.9 & (Jinsong He 2014) \\
\hline & Chlorella vulgaris & 5.0 & 1440 & 0.10 & 58.40 & (Monika et al. 2014) \\
\hline & Spirogyra insignis & 6 & 120 & 0.30 & 17.5 & (Romera et al. 2007) \\
\hline & Codium vermilara & 6 & 120 & 0.22 & 13.2 & (Romera et al. 2007) \\
\hline & Neochloris pseudoalveolaris & 6 & 10 & 0.92 & 53.93 & (K1zılkaya et al. 2012) \\
\hline & Scenedesmus quadricauda & 6 & 10 & 1.09 & 64.25 & (K1zılkaya et al. 2012) \\
\hline
\end{tabular}


Table 6 (continued)

\begin{tabular}{lllllll}
\hline Metal Ions & Species of Algae & $\mathrm{pH}$ & Eq. Time $(\mathrm{min})$ & $\mathrm{q}_{\max }(\mathrm{mmol} / \mathrm{g})$ & $\mathrm{q}_{\max }(\mathrm{mg} / \mathrm{g})$ & References \\
\hline & Chlorella vulgaris & 4.7 & - & 0.41 & 24.06 & $\begin{array}{c}\text { (Romera et al. 2006) (Klimmek } \\
\text { et al. 2001) } \\
\text { Chlorella vulgaris }\end{array}$ \\
Chlorella vulgaris & 5 & - & & 1.017 & 59.69 & (Romera et al. 2006) \\
(Romera et al. 2006)
\end{tabular}

In general, nitrogen depletion $(-\mathrm{N})$ for both species of algal cells causes a decrease in biosorption capacities for $\mathrm{Pb}^{2+}$ but an increase for $\mathrm{Zn}^{2+}$ and $\mathrm{Cu}^{2+}$. In the cases of $\mathrm{Cd}^{2+}$ and $\mathrm{Ni}^{2+}$, nitrogen depletion $(-\mathrm{N})$ causes a decrease in the biosorption capacity for $N$. alveolaris but an increase for $N$. minuta.

\section{Conclusions}

The results of this study indicate that the type of algae, $N$. minuta and $N$. alveolaris, and the composition of the algae based on nitrogen deprivation $(+\mathrm{N}$ versus $-\mathrm{N})$ changes the biosorption capacities and percentage adsorption efficiencies for five heavy metals. As algae start growing in contaminated waters with heavy metals, their nitrogen source can get depleted affecting their biosorption capacities and adsorption efficiencies. In the cases of $N$. minuta and $N$. alveolaris, nitrogen depletion causes a decrease in biosorption capacities for $\mathrm{Pb}^{2+}$ but an increase for $\mathrm{Zn}^{2+}$ and $\mathrm{Cu}^{2+}$. In the cases of $\mathrm{Cd}^{2+}$ and $\mathrm{Ni}^{2+}$, nitrogen depletion causes a decrease in the biosorption capacity for $N$. alveolaris, but an increase for $N$. minuta. The nitrogen content needs to be adjusted depending on the algal species and the metal being adsorbed. The metal ion biosorption capacities, $\mathrm{q}_{\max }$, of the four algae followed the sequence: $\mathrm{Pb}^{2+}>\mathrm{Cd}^{2+}>\mathrm{Zn}^{2+}>\mathrm{Cu}^{2+}>$ and $\mathrm{Ni}^{2+}$. The maximum adsorption capacities match the high affinity of biosorption of the metals. These results demonstrate that biomass modified algae can be used to selectively improve the biosorption capacities and adsorption efficiencies of certain metal ions.

Supplementary Information The online version of this article (https:// doi.org/10.1007/s13201-021-01363-y) contains supplementary material, which is available to authorized users.

Funding The author(s) received no specific funding for this work.

\section{Compliance with ethical standards}

Conflict of Interest The authors declare that they have no conflict of interest.

Open Access This article is licensed under a Creative Commons Attribution 4.0 International License, which permits use, sharing, adaptation, distribution and reproduction in any medium or format, as long as you give appropriate credit to the original author(s) and the source, provide a link to the Creative Commons licence, and indicate if changes were made. The images or other third party material in this article are included in the article's Creative Commons licence, unless indicated otherwise in a credit line to the material. If material is not included in the article's Creative Commons licence and your intended use is not permitted by statutory regulation or exceeds the permitted use, you will need to obtain permission directly from the copyright holder. To view a copy of this licence, visit http://creativecommons .org/licenses/by/4.0/.

\section{References}

Abbas SH, Ismail IM, Mostafa TM, Sulaymon AH (2014) Biosorption of heavy metals: a review. J Chem Sci Technol 3:74-102

Abbas A, Hussain MA, Sher M, Irfan MI, Tahir MN, Tremel W, Hussain SZ, Hussain I (2017) Design, characterization and evaluation of hydroxyethylcellulose based novel regenerable supersorbent for heavy metal ions uptake and competitive adsorption. Int J Biol Macromol 102:170-180

Abu Qdais H, Moussa H (2004) Removal of heavy metals from wastewater by membrane processes: a comparative study. Desalination 164:105-110

Ahmed I, Iqbal HMN, Dhama K (2017) Enzyme-based biodegradation of hazardous pollutants - an overview. J Exp Biol Agric Sci 5:402-411

Anderson RA (2005) Algal culturing techniques, 1st edn. Academic Press

Barrios-Estrada C, Rostro-Alanis MD, Munoz-Gutierrez BD, Iqbal HMN, Kannan S, Parra-Saldivar R (2018) Emergent contaminants: endocrine disruptors and their laccase-assisted degradation - a review. Sci Total Environ 612:1516-1531

Bilal M, Rasheed T, Sosa-Hernández JE, Raza A, Nabeel F, Iqbal H (2018) Biosorption: an interplay between marine algae and potentially toxic elements - a review. marine drugs, 16: 1-16.

Chan A, Salsali H, McBean E (2014) Heavy metal removal (copper and zinc) in secondary effluent from wastewater treatment plants by microalgae. Acs Sustain Chem Eng 2:130-137

Charerntanyarak L (1999) Heavy metals removal by chemical coagulation and precipitation. Water Sci Technol 39:135-138

Dabrowski A, Hubicki Z, Podkoscielny P, Robens E (2004) Selective removal of the heavy metal ions from waters and industrial wastewaters by ion-exchange method. Chemosphere 56:91-106

Davis TA, Volesky B, Mucci A (2003) A review of the biochemistry of heavy metal biosorption by brown algae. Water Res 37:4311-4330

Gupta VK, Rastogi A (2008) Equilibrium and kinetic modelling of cadmium(II) biosorption by nonliving algal biomass Oedogonium sp from aqueous phase. J Hazard Mater 153:759-766

Gupta VK, Jain R, Nayak A, Agarwal S, Shrivastava M (2011) Removal of the hazardous dye-Tartrazine by photodegradation on titanium dioxide surface. Mater Sci Eng C-Mater Biol Appl 31:1062-1067 
Gupta VK, Ali I, Saleh TA, Nayak A, Agarwal S (2012) Chemical treatment technologies for waste-water recycling-an overview. Rsc Advances 2:6380-6388

Hameed BH, Din ATM, Ahmad AL (2007) Adsorption of methylene blue onto bamboo-based activated carbon: kinetics and equilibrium studies. J Hazard Mater 141:819-825

Hastings G, Thomas J, Witt K, Giarikos D, Razeghifard R (2018) Starch lipid, and protein accumulation in nutrient-stressed microalgal cells studied using fourier transform infrared microscopy. Front Sci Technol Eng Math 2:121-129

Heller HF, Wilfried (1939) The adsorption of cis- and trans-azobenzene. J Am Chem Soc 61:2228-2230

Jiang XC, Zhou XD, Li CY, Wan ZJ, Yao LG, Gao PC (2019) Adsorption of copper by flocculated Chlamydomonas microsphaera microalgae and polyaluminium chloride in heavy metal-contaminated water. J Appl Phycol 31:1143-1151

Jinsong He J, Chen P (2014) A comprehensive review on biosorption of heavy metals by algal biomass: Materials, performances, chemistry, and modeling simulation tools. Biores Technol 160:67-78

Kaparapu J, Prasad MK (2018) Equilibrium, kinetics and thermodynamic studies of cadmium(II) biosorption on Nannochloropsis oculata. Appl Water Sci 8(6):179

Kasimani R, Seenivasagan R, Sundar K (2017) Optimization of growth medium and biosorption of chromium using micro algae and cyanobacteria. Bioremediation and Sustainable Technologies for Cleaner Environment, pp 347-358

Kızılkaya B, Türker G, Akgül R, Doğan F (2012) Comparative study of biosorption of heavy metals using living green algae scenedesmus quadricauda and neochloris pseudoalveolaris: equilibrium and kinetics. J Dispersion Sci Technol 33:410-419

Klimmek S, Stan HJ, Wilke A, Bunke G, Buchholz R (2001) Comparative analysis of the biosorption of cadmium, lead, nickel, and zinc by algae. Environ Sci Technol 35(21):4283-4288

Kumar M, Singh AK, Sikandar M (2018) Study of sorption and desorption of Cd (II) from aqueous solution using isolated green algae Chlorella vulgaris. Appl Water Sci 8(8):225

Langmuir I (1918) The adsorption of gases on plane surfaces of glass, mica and platinum. J Am Chem Soc 40:1361-1403

Lee SM, Laldawngliana C, Tiwari D (2012) Iron oxide nano-particlesimmobilized-sand material in the treatment of $\mathrm{Cu}(\mathrm{II}), \mathrm{Cd}(\mathrm{II})$ and $\mathrm{Pb}$ (II) contaminated waste waters. Chem Eng J 195:103-111

Li YT, Song SX, Xia L, Yin HQ, Meza JVG, Ju WM (2019) Enhanced $\mathrm{Pb}$ (II) removal by algal-based biosorbent cultivated in high-phosphorus cultures. Chem Eng J 361:167-179

Lourenco SO, Barbarino E, Lavin PL, Marque UML, Aidar E (2004) Distribution of intracellular nitrogen in marine microalgae: calculation of new nitrogen-to-protein conversion factors. Eur J Phycol 39:17-32

Matei GM, Kiptoo JK, Oyaro N, Onditi AO (2015) Biosorption of selected heavy metals by green algae, spirogyra species and its potential as a pollution biomonitor. Chem Mater Res 7(7):42-52
Monika B, Alka S, Srivastava JK, Palsania J (2014) Biosorption of heavy metals from wastewater by using microalgae. Int J Chem Phys Sci 3(6):67-81

Moreira VR, Lebron YAR, Freire SJ, Santos LVS, Palladino F, Jacob RS (2019) Biosorption of copper ions from aqueous solution using Chlorella pyrenoidosa: optimization, equilibrium and kinetics studies. Microchem J 145:119-129

Nazal MK (2019) Marine algae bioadsorbents for adsorptive removal of heavy metals. In: Advanced sorption process applications. https ://doi.org/10.5772/intechopen.80850

Ncibi MC, Altenor S, Seffen M, Brouers F, Gaspard S (2008) Modelling single compound adsorption onto porous and non-porous sorbents using a deformed Weibull exponential isotherm. Chem Eng J 145:196-202

Nirmal Kumar JI, Oommen C, Kumar RN (2009) Biosorption of heavy metals from aqueous solution by green marine macroalgae from Okha Port, Gulf of Kutch, India American-Eurasian. J Agric Environ Sci 6(3):317-323

Park D, Yun YS, Park JM (2010) The past, present, and future trends of biosorption. Biotechnol Bioprocess Eng 15:86-102

Pearson RG (1990) Hard and soft acids and bases - the evolution of a chemical concept. Coord Chem Rev 100:403-425

Rangbhashiyam S, Balasubramanian P (2019) Characteristics, performances, equilibrium and kinetic modeling aspects of heavy metal removal using algae. Bioresour Technol Rep 5:261-279

Richards S, Dawson J, Stutter M (2019) The potential use of natural vs commercial biosorbent material to remediate stream waters by removing heavy metal contaminants. J Environ Manage 231:275-281

Romera E, González F, Ballester A, Blázquez ML, Muñoz JA (2006) Biosorption with algae: a statistical review. Crit Rev Biotechnol 26(4):223-235

Romera E, Gonzalez F, Ballester A, Blazquez ML, Munoz JA (2007) Comparative study of biosorption of heavy metals using different types of algae. Biores Technol 98:3344-3353

Sheng PX, Ting YP, Chen JP, Hong L (2004) Sorption of lead, copper, cadmium, zinc, and nickel by marine algal biomass: characterization of biosorptive capacity and investigation of mechanisms. J Colloid Interface Sci 275:131-141

Yuan C, Weng CH (2006) Electrokinetic enhancement removal of heavy metals from industrial wastewater sludge. Chemosphere 65:88-96

Zeraatkar AK, Ahmadzadeh H, Talebi AF, Moheimani NR, McHenry MP (2016) Potential use of algae for heavy metal bioremediation, a critical review. J Environ Manage 181:817-831

Publisher's Note Springer Nature remains neutral with regard to jurisdictional claims in published maps and institutional affiliations. 